\title{
Traveltime Data for Truckee River Between Tahoe City, California, and Marble Bluff Dam Near Nixon, Nevada, 1999
}

By E. James Crompton and Larry R. Bohman

U.S. GEOLOGICAL SURVEY

Open-File Report 00-363

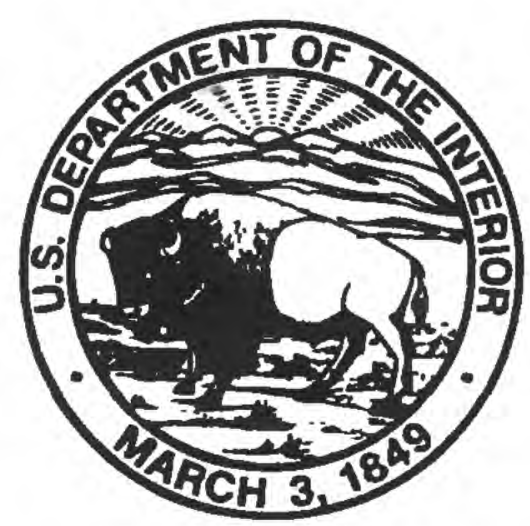

Carson City, Nevada 2000 


\title{
U.S. DEPARTMENT OF THE INTERIOR BRUCE BABBITT, Secretary
}

\author{
U.S. GEOLOGICAL SURVEY \\ CHARLES G. GROAT, Director
}

Any use of trade, product, or firm names in this publication is for descriptive purposes only and does not imply endorsement by the U.S. Govemment

For additional information contact:

\section{District Chief}

U.S. Geological Survey

333 West Nye Lane, Room 203

Carson City, NV 89706-0866

email: GS-W-NVpublic_info@usgs.gov

http://nevada.usgs.gov
Copies of this report can be purchased from:
U.S. Geological Survey
Information Services
Building 810
Box 25286, Federal Center
Denver, CO 80225-0286 


\section{CONTENTS}

Abstract.

Introduction

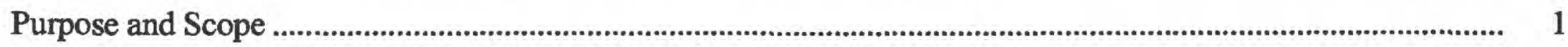

Previous Dye-Tracing Investigations in Study Area ...........................................................................................

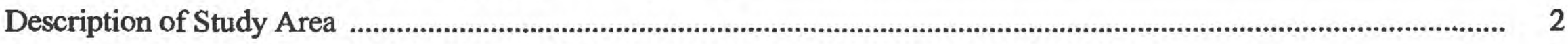

Data Collection, Quality Assurance, and Results .................................................................................................

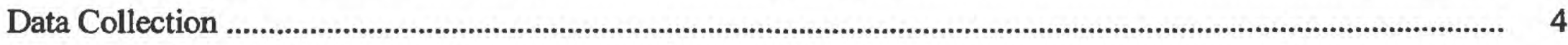

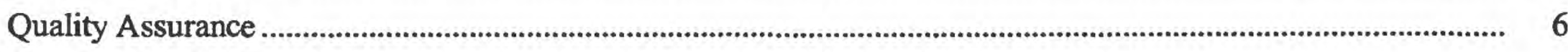

Dye-Tracing Results ............................................................................................................................................... 7

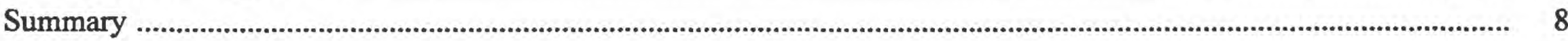

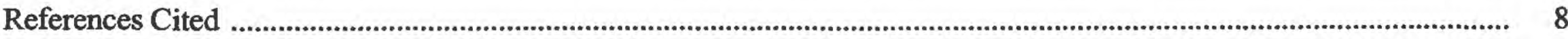

\section{FIGURES}

1. Map showing general location of Truckee River gaging stations and injection or sampling sites used in traveltime studies

2-9. Graphs showing observed response curves for Truckee River between:

2. Mogul, Nev., and Vista, Nev., May 4, 1999

3. Steamboat Creek at mouth near Sparks, Nev., and Wadsworth, Nev., April 30-May 1, 1999.

4. Wadsworth, Nev., and Marble Bluff Dam near Nixon, Nev., April 28, 1999 .................................................... 19

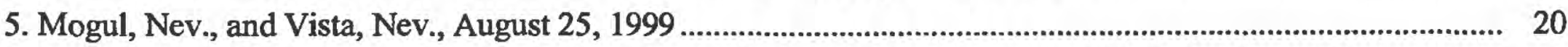

6. Steamboat Creek at mouth near Sparks, Nev., and Wadsworth, Nev., August 18-20, 1999 .......................... 21

7. Wadsworth, Nev., and Marble Bluff Dam near Nixon, Nev., August 16-17, 1999 ......................................... 22

8. Tahoe City, Calif., and Boca Bridge near Truckee, Calif., September 14-15, 1999...................................... 23

9. Old U.S. Highway 40 bridge near Truckee, Calif., and Mogul, Nev., September 19-20, 1999....................... 24

\section{TABLES}

1. Truckee River traveltime-study injection and sampling sites and selected U.S. Geological Survey streamflow-gaging stations

2-9. Dye-concentration data from traveltime study on Truckee River between:

2. Mogul, Nev., and Vista, Nev., May 4, 1999

3. Steamboat Creek at mouth near Sparks, Nev., and Wadsworth, Nev., April 30-May 1, 1999 ......................... 10

4. Wadsworth, Nev., and Marble Bluff Dam near Nixon, Nev., April 28, 1999 ................................................... 11

5. Mogul, Nev., and Vista, Nev., August 25, 1999 .......................................................................................... 12

6. Steamboat Creek at mouth near Sparks, Nev., and Wadsworth, Nev., August 18-20, 1999 ........................... 13

7. Wadsworth, Nev., and Marble Bluff Dam near Nixon, Nev., August 16-17, 1999 ......................................... 14

8. Tahoe City, Calif., to Boca Bridge near Truckee, Calif., September 14-15, 1999.......................................... 15

9. Old U.S. Highway 40 bridge near Truckee, Calif., and Mogul, Nev., September 19-20, 1999........................ 16 
CONVERSION FACTORS, ABBREVIATED WATER-QUALITY UNITS, AND VERTICAL DATUM

\begin{tabular}{rll}
\hline Multiply & By & To obtaln \\
foot $(\mathrm{ft})$ & 0.3048 & meter \\
mile $(\mathrm{mi})$ & 1.609 & kilometer \\
square mile $\left(\mathrm{mi}^{2}\right)$ & 2.590 & square kilometer \\
pound $(\mathrm{lb})$ & 0.4536 & kilogram \\
gallon $(\mathrm{gal})$ & 3.785 & liter \\
cubic foot $\left(\mathrm{ft}^{3}\right)$ & 0.02832 & cubic meter \\
foot per mile $\left(\mathrm{ft} / \mathrm{mi}^{2}\right)$ & 0.1894 & meter per kilometer \\
foot per second $(\mathrm{ft} / \mathrm{s})$ & 0.3048 & meter per second \\
cubic foot per second $\left(\mathrm{ft}^{3} / \mathrm{s}\right)$ & 0.02832 & cubic meter per second \\
mile per hour $(\mathrm{mi} / \mathrm{h})$ & 1.609 & kilometer per hour \\
ounce $(\mathrm{oz})$ & 29.57 & milliliter \\
\hline
\end{tabular}

\footnotetext{
Abbreviated water-quality units used in this report:

$\mathrm{g} / \mathrm{L}$, gram per liter

$\mu \mathrm{g} / \mathrm{L}$, microgram per liter
}

Sea level: In this report, "sea level" refers to the National Geodetic Vertical Datum of 1929 (NGVD of 1929, formerly called "SeaLevel Datum of 1929"), which is derived from a general adjustment of the first-order leveling networks of the United States and Canada. 


\section{Traveltime Data for Truckee River Between Tahoe City, California, and Marble Bluff Dam Near Nixon, Nevada, 1999}

\author{
By E. James Crompton and Larry R. Bohman
}

\section{INTRODUCTION}

The use of dyes and tracing techniques provides a means of measuring the traveltime and dispersion characteristics of streams. Traveltime may be defined as the time it takes for water or soluble constituents introduced into a river to move downstream from one point to another. Introduced constituents also tend to disperse as they move downstream, causing peak concentrations to decrease and the length of the solute plume to increase. Dye tracing involves the instantaneous injection of a nontoxic, fluorescent dye at a location along the stream and sampling of the resulting dye plume at locations downstream (Buchanan, 1964; Wilson, 1968). The dye mixes with the water and moves in the same manner as the water. Traveltime is measured as the time required for movement of the centroid or center of mass of the dye plume between sampling sites. Dispersion is characterized by the time of passage of the solute plume and attenuation of the peak concentration as the plume moves downstream. Dye studies typically are made over a range of streamflows that are indexed to flows at selected stream-gaging stations.

Information on traveltime of solutes may be required for water-quality modeling or waste-transport studies and also provides an objective means for determining an appropriate course of action in response to the spilling of a soluble toxic substance. For the former purpose, the model results are usually no better quantitatively than the traveltime data used in their development because simulation of biochemical processes in water-quality models involves the calculation of timedependent reactions. Although mean streamflow velocity may be computed from streamflow measurements made at gaging stations, such point data may not adequately characterize an entire stream reach. Extrapolation of such point data may be subject to large errors. For the latter purpose, officials responsible for public safety (including water-supply managers and regulators) and others interested in transient waterquality problems need to be able to predict passage and arrival times or peak concentration of a noxious substance released or spilled upstream. Accurate traveltime information is needed to provide a reasonable basis for deciding whether, when, and how long to suspend operations of public water-supply intakes or how best to handle any perceived threat to the river environment.

\section{Purpose and Scope}

This report describes the techniques and presents the results (in tabular and graphical form) of eight dyetracing studies made during two flow regimes on the Truckee River between Tahoe City, Calif., and Marble Bluff Dam near Nixon, Nev. (approximately $3 \mathrm{mi}$ upstream from Pyramid Lake) during 1999. Three of the eight studies were made during high flow (greater than $2,000 \mathrm{ft}^{3} / \mathrm{s}$ ), and five during medium flow (173 to $627 \mathrm{ft}^{3} / \mathrm{s}$ ). The high-flow studies were done during April and May, and the medium-flow studies during August and September. 


\section{Previous Dye-Tracing Investigations in Study Area}

La Camera and others (1985) published, in tabular form, the physical, chemical, and biological data collected as part of the Truckee-Carson river-quality assessment (Nowlin and others, 1980) in support of water-quality modeling and investigations of troutspawning habitats in the Truckee River system.

La Camera and others (1985) included the results from 13 dye-tracer studies during the period $1979-80$ for a wide range of flows in three reaches along the Truckee River-from Truckee, Calif., to Vista, Nev.; Vista to Derby Diversion Dam (hereafter, "Derby Dam") near Wadsworth, Nev.; and Derby Dam to Marble Bluff Dam near Nixon, Nev.

Brown and others (1986) analyzed the data published by La Camera and others (1985) and provided an overview of the hydrologic system of the Truckee River and Carson River Basins; presented data and computed relations in graphical, tabular, and map form; and interpreted the raw and computed data. The computed relations then were used in equations to relate velocities to flows in 43 reaches of the Truckee River from Sparks to Pyramid Lake for water-quality modeling (Nowlin, 1987). The velocity-flow relations developed by Nowlin (1987) also were used in more recent water-quality models of the Truckee River (Caupp and others, 1997).

Bohman (2000) did four traveltime studies during low-flow conditions (12 to $161 \mathrm{ft}^{3} / \mathrm{s}$ ) on the Truckee River during November and December 1993. The four river reaches studied by Bohman (2000) were from the confluence of Steamboat Creek and the Truckee River near Sparks, Nev., to Derby Dam near Wadsworth, Nev.; from Derby Dam near Wadsworth, Nev., to Wadsworth, Nev.; from Wadsworth, Nev., to Dead Ox Wash near Nixon, Nev.; and from Dead Ox Wash near Nixon, Nev., to Marble Bluff Dam near Nixon, Nev. He tabulated and combined the 1993 data with earlier data from La Camera and others (1985) and presented graphical relations between traveltime and distance and between traveltime and flow.

\section{DESCRIPTION OF STUDY AREA}

A detailed description of the physical and hydrologic characteristics of the Truckee River was given by Van Denburgh and others (1973), Brown and others (1986), and the Jones and others (1991). The following paragraphs briefly describe the physical setting of the
Truckee River. A general location map of the study area, including the relevant streamflow-gaging stations and dye-study sites, is shown in figure 1.

The Truckee River watershed is a topographically enclosed basin on the eastern slope of the Sierra Nevada along the California-Nevada border. In the part of the basin that surrounds Lake Tahoe, headwater altitudes exceed $10,000 \mathrm{ft}$ above sea level. The lowest part of the basin is at the river's terminus, Pyramid Lake, where the altitude is approximately $3,795 \mathrm{ft}$ above sea level. The total drainage area of the basin is $3,120 \mathrm{mi}^{2}$, but only $1,940 \mathrm{mi}^{2}$ contributes streamflow to the 116-mi-long stretch of the Truckee River above Marble Bluff Dam (about 3 mi upstream from the mouth at Pyramid Lake).

From the outlet of Lake Tahoe, the Truckee River flows generally north about 15 mi to Truckee, Calif., then northeasterly for about $28 \mathrm{mi}$ across the State line to Verdi, Nev. Downstream from Verdi, the river flows to the east about $21 \mathrm{mi}$ to Vista, Nev. Several major tributaries, all of which are controlled by reservoirs, join the Truckee River downstream from Tahoe City, they include Donner Creek, Martis Creek, Prosser Creek and the Little Truckee River. Just downstream from the mouth of the Little Truckee River, the Truckee River flows through a deeply incised canyon to the California-Nevada border. About $8 \mathrm{mi}$ east of the border, the river passes through an alluvial valley bounded

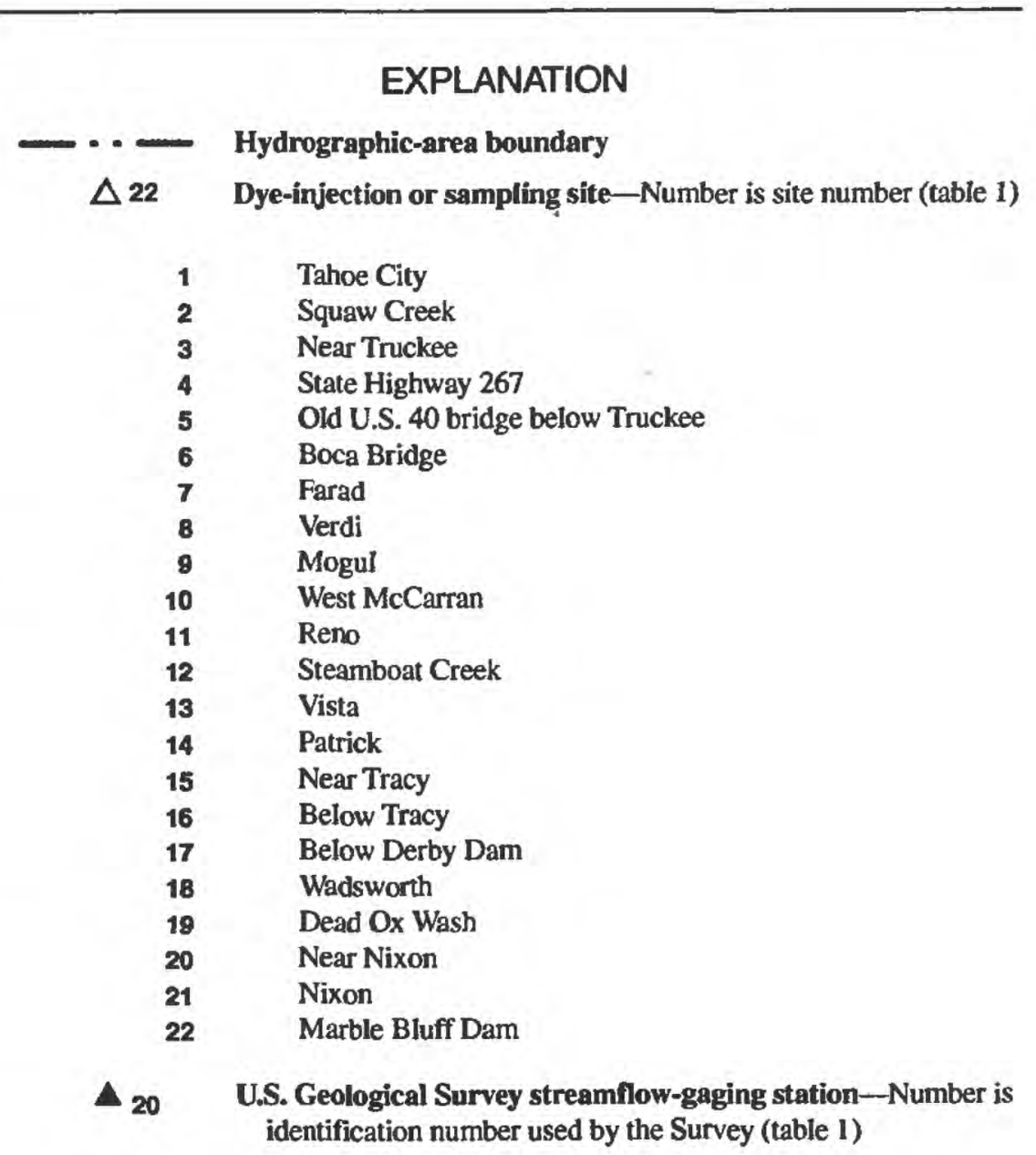




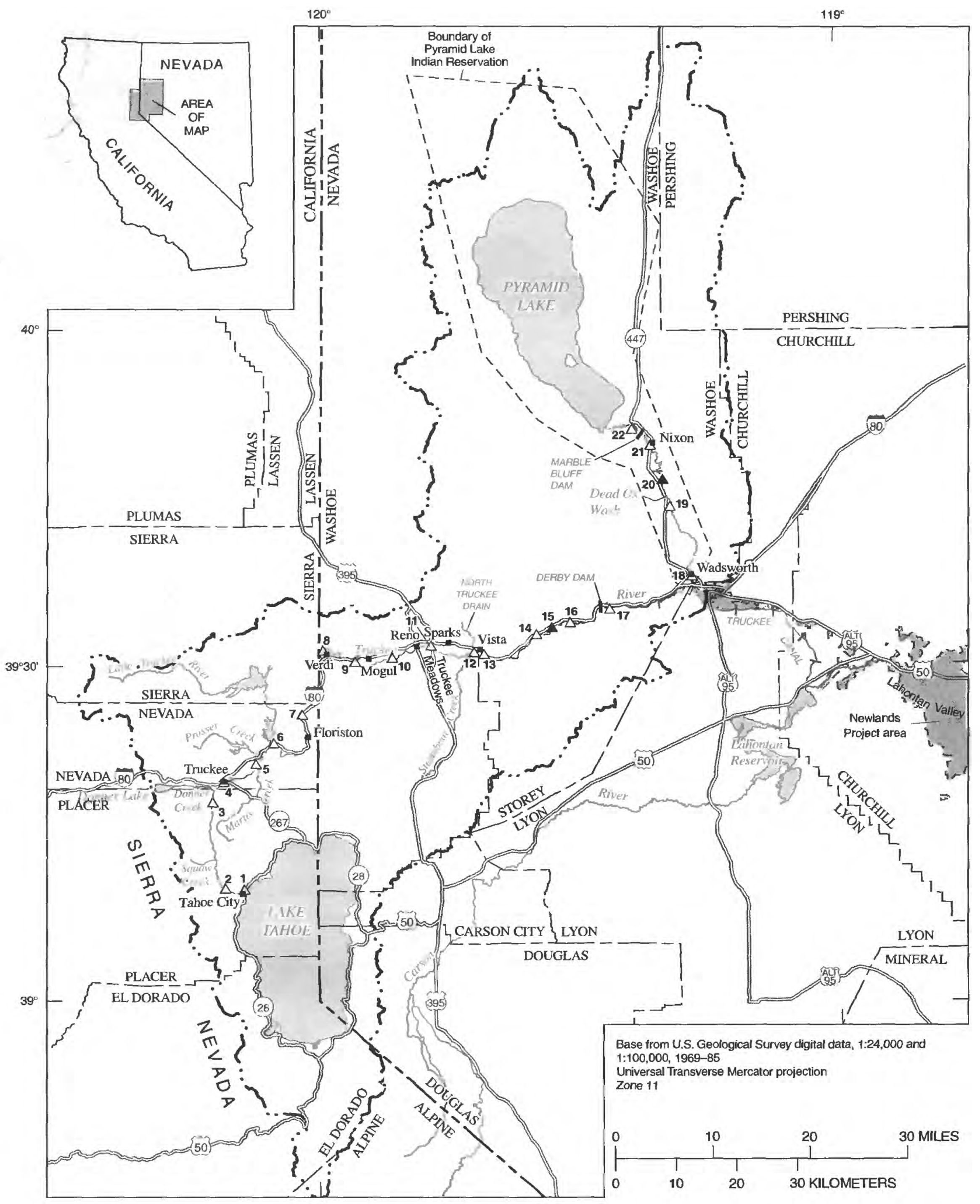

Figure 1. General location of Truckee River gaging stations and injection or sampling sites used in traveltime studies. Old U.S. Highway 40 (Glenshire Road in parts of California or State Route 427 in parts of Nevada) is not shown on map; at map scale, it roughly parallels Interstate 80 . See table 1 for full site names and other alternate route names. 
by mountain ranges. This area, known as the Truckee Meadows, includes the rapidly growing cities of Reno and Sparks. Although the current economy of the area is dominated by gaming and tourism, Truckee Meadows still contains irrigated agricultural lands. Both municipal and agricultural water needs are satisfied by diversions at 10 locations along the river within and upstream from the Truckee Meadows. Two hydroelectric plants are located in the western part of the Truckee Meadows; both these plants are run-of-river and divert part of the streamflow from the Truckee River near Verdi. Irrigation return flows from diversions originating on the north side of the river between Verdi and Reno and some natural flow enter the Truckee River via the North Truckee Drain near Vista, just east of Sparks. Irrigation return flows from diversions originating on the south side of the river between Verdi and Sparks, treated municipal-sewage effluent, and additional natural flows enter the river from Steamboat Creek, also near Sparks. The Truckee Meadows Water Reclamation Facility (formerly called the Reno-Sparks sewage-treatment plant) is near the mouth of Steamboat Creek.

Downstream from the Truckee Meadows, the river parallels Interstate 80 eastward for about $29 \mathrm{mi}$ through arid canyon terrain to Wadsworth, Nev. At Wadsworth, the river turns north and continues for about $23 \mathrm{mi}$ through the Pyramid Lake Indian Reservation to Marble Bluff Dam downstream from Nixon, Nev. Tributaries below Vista, Nev., are ephemeral; large flows are mostly in response to heavy precipitation, usually as summer thunderstorms. Downstream from Wadsworth, the channel is unstable in many areas and therefore is subject to lateral shifting within the flood plain during major floods. Population is sparse, limited to the communities of Wadsworth and Nixon and a few private ranches. The irrigation needs of small ranches bordering the lower Truckee River below Vista are served by 11 diversions. The largest diversion in this reach is the Truckee Canal. At Derby Dam (about $19 \mathrm{mi}$ downstream from Vista), the canal diverts water from the river southeastward into Lahontan Reservoir in the Carson River Basin. The approximately 31-milong canal was constructed by the Bureau of Reclamation (U.S. Department of the Interior) as part of the Newlands Project, the Nation's first project completed under the authority of the Reclamation Act of 1902 (Jones and others, 1991, p. 23).
River gradients vary between the lower basin and the steeper mountain-block area of the upper basin. The gradient of the river is fairly steep above Reno, averaging about $35 \mathrm{ft} / \mathrm{mi}$. Within the $8-\mathrm{mi}$ reach of the river between Reno and Vista, the gradient is relatively flat (about $1.6 \mathrm{ft} / \mathrm{mi}$ ). From Vista to Marble Bluff Dam, the Truckee River channel slope averages less than 10 $\mathrm{ft} / \mathrm{mi}$. The numerous diversion structures have important localized effects on the channel slope. Resultant decreases in flow velocities and increases in flow depths upstream from diversion structures undoubtedly influence both traveltime and dispersion characteristics of the river (Nowlin, 1987).

\section{DATA COLLECTION, QUALITY ASSURANCE, AND RESULTS}

This report presents the results of eight dye-tracing studies. Three studies were made under high-flow conditions between Mogul, Nev., and Marble Bluff Dam near Nixon, Nev., during April-May 1999, and five studies under medium-flow conditions between Tahoe City, Calif., and Marble Bluff Dam near Nixon, Nev., during August-September 1999. Locations of the streamflow-gaging stations and dye-study sites, are shown in figure 1; sampling and injection sites are listed in table 1 . This section of the report provides an overview of the field and laboratory procedures used to collect the data, quality-assurance methods, and the results of the tracer studies.

\section{Data Collection}

Field procedures for traveltime and dispersion studies on streams using dye tracers are well documented (Kilpatrick and Wilson, 1989). In general, those procedures were followed closely during the 1999 Truckee River studies.

The five Truckee River reaches studied in 1999 were from Tahoe City, Calif., to Boca Bridge near Truckee, Calif.; from the old U.S. Highway 40 bridge near Truckee, Calif., to Mogul, Nev.; from Mogul, Nev., to Vista, Nev.; from Steamboat Creek at its mouth near Sparks, Nev., to Wadsworth, Nev.; and from Wadsworth, Nev., to Marble Bluff Dam near Nixon, Nev. For each study reach, a minimum of three sampling sites downstream from the injection point

\footnotetext{
${ }^{1}$ Old U.S. Highway 40 is now known as Glenshire Road.
} 


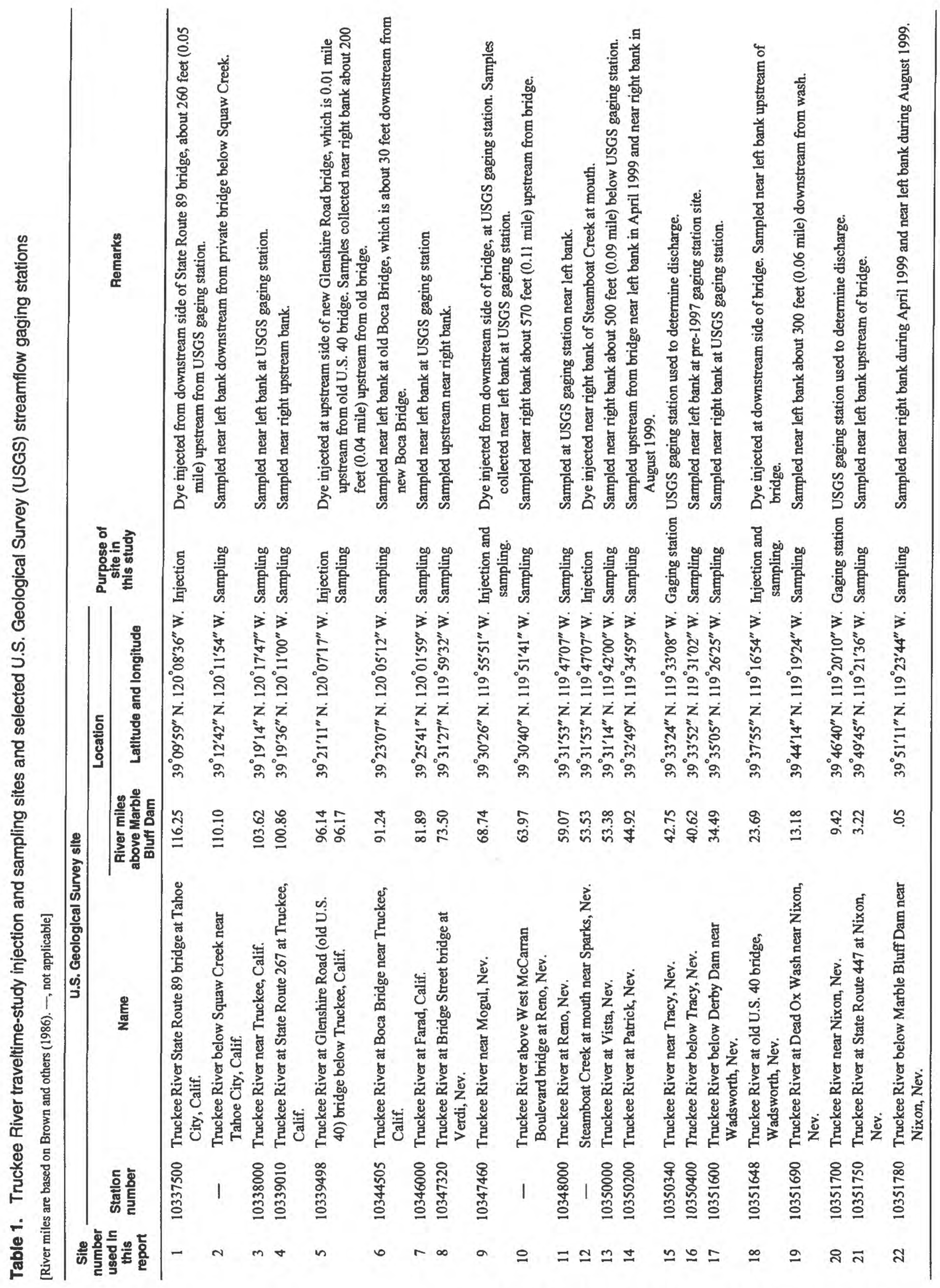

DATA COLLECTION, QUALITY ASSURANCE, AND RESULTS 5 
were selected. Accessibility and suitability for making streamflow measurements over a range of flows were considered in site selection. Sampling sites were far enough downstream from the injection sites that complete lateral mixing could be assumed. Tributary inflows, analogous to a side injection of clear water, cause lateral-mixing problems at nearby downstream sampling sites. Dye-measurement sites were chosen to be sufficiently downstream from tributary inflows for the water and dye to be fully mixed. Despite these precautions, Little Truckee River and Steamboat Creek inflows may have caused poor mixing at Boca Bridge near Truckee (site 6) and at Vista (site 13), respectively, during the medium-flow studies.

Single-slug (instantaneous) dye injections usually were made near the center of active flow. Rhodamine WT dye was used in the studies because it is less susceptible than other dye types to loss by contact with aquatic plants, suspended clays, and the streambed and streambanks. For each injection, the type and amount of dye, time and location of injection, and the measured streamflow were recorded. The amount of dye to be injected at the upstream end of each study reach was determined by using general empirical relations (Kilpatrick and Wilson, 1989) that are dependent upon the maximum streamflow anticipated for the reach, velocity, reach length, and dye concentration. These dye amounts typically were chosen so peak concentrations at the downstream end of each study reach or at municipal water intakes did not exceed $10 \mu \mathrm{g} / \mathrm{L}$.

Fluorometers were used in the field and in the laboratory to determine the presence and concentration of dye in the samples collected. Fluorometers measure the luminescence of a fluorescent substance when that substance is subjected to a light source of an appropriate wavelength. The higher the concentration of the fluorescent substance, the more emitted light the fluorometer detects. Control samples taken at each site indicate that the background concentration was $0.04 \mu \mathrm{g} / \mathrm{L}$ or less in the river. When the dye plume arrived at a given site, 14 to 34 samples were taken in the main flow of the river at time intervals adequate to define the timeconcentration (response) curve. Samples were collected manually at single points in the river. Fluorometer measurements were made in the field at the time of sampling to guide the frequency and duration of sampling for each dye plume. After field measurement, samples were stored out of sunlight in 1-oz glass bottles for later analysis under laboratory conditions.
Streamflow measurements were made at the injection site and at each sampling site. In those instances where direct streamflow measurements were not made while dye was present, streamflow-gagingstation data from nearby stations were substituted or were used to estimate the flow within a reach during the period when dye was present. Also, diversion data ( 20 sites) and return data (4 sites) were obtained from the Federal Water Master, Dave Wathen (U.S. District Court, written commun., 1999). In the reach from Farad (site 7) to Mogul (site 9) about 18 percent of the flow was diverted from the Truckee River for irrigation and municipal uses during September. During August about $130 \mathrm{ft}^{3} / \mathrm{s}$ was diverted through the Truckee Canal, which is upstream from the sampling site below Derby Dam near Wadsworth (site 17).

The samples collected in the field were reanalyzed under more-controlled laboratory conditions because sample temperatures experienced in the field varied and were different from those used to calibrate the fluorometer. Aside from dye concentration, sample temperature is the most significant factor affecting the fluorescence of a dilute solution. The fluorometer was calibrated in the lab according to procedures described by Wilson and others (1986) using standard solutions prepared from the same dye lot that had been used in the field. The raw data shown in tables and used in figures in this report are the actual dye-concentration values that were obtained under laboratory conditions; they were not adjusted to conservative values on the basis of dye-recovery percentages.

\section{Quality Assurance}

Quality-assurance procedures used in this study involved comparing field and laboratory measurements of dye concentrations, analyzing plots of dye concentrations, and conserving dye mass.

In general, dye-concentration values recorded in the laboratory differed slightly from those measured in the field; however, the trend in concentration was consistent between field and laboratory values.

Plotted dye concentrations were compared to expected patterns and within a given reach. The dye curves were similar to those presented by Kilpatrick and Wilson $(1989$, p. 3$)$, in that the peak concentration was reduced and the dye plume increased in length as it moved downstream.

In addition to streamflow measurements and U.S. Geological Survey (USGS) gaging-station data, data on agricultural and municipal diversions (20 sites) and 
on returns (4 sites) were obtained from the files of the Federal Water Master, Dave Wathen (U.S. District Court, written commun., 1999).

The amount of dye recovered at each sampling site was determined on the basis of measured streamflows and on dye concentrations. Recovered amounts were compared to the amounts of dye injected and amounts of dye recovered at other sites within the same study.

\section{Dye-Tracing Results}

Data collected during the 1999 studies are presented in tables 2 through 9 and are plotted in figures 2 through 9. The tabulated data include injection place, time, and volume; sampling sites, and distance from injection; and streamflows during sampling period; sampling times; and dye concentrations. The dye-concentration values show the amount of dispersal in the dye plume and the timing and location of the peak concentration.

Data for the Truckee River reach from Tahoe City, Calif., to Boca Bridge near Truckee, Calif., is presented in table 8; for the reach from the old U.S. Highway 40 bridge near Truckee, Calif., to Mogul, Nev., in table 9; for Mogul, Nev., to Vista, Nev., in tables 2 and 5; for Steamboat Creek at its mouth near Sparks, Nev., to Wadsworth, Nev., in tables 3 and 6; and for Wadsworth, Nev., to Marble Bluff Dam near Nixon, Nev., in tables 4 and 7.

During the high-flow study regime, flows ranged from 2,130 to 2,780 $\mathrm{ft}^{3} / \mathrm{s}$ (tables 2 through 4). For the sites at Patrick and below Tracy (sites 14 and 16, table 3 ), discharges had to be estimated on the basis of discharge measurements made at the USGS streamflowgaging station near Tracy (site 15). For the site below Marble Bluff Dam near Nixon (site 22, table 4), the no initial background sample was collected, the first sampling was done after the dye had arrived and possibly after the peak had passed.

Where either the first sample at a site was collected after the dye had arrived or the last sample, before the dye concentrations reached $0.2 \mu \mathrm{g} / \mathrm{L}$, the values were derived from graphical analyses of the raw data according to the methods described by Kilpatrick and Wilson (1989).

During the medium-flow study regime, flows ranged from 173 to $627 \mathrm{ft}^{3} / \mathrm{s}$ (tables 5 through 9). As at high flow, for the site at Patrick (site 14, table 6) streamflow was estimated from data collected at the USGS streamflow-gaging station near Tracy (site 15). Similarly, discharge measurements for the sites at State
Highway 447 at Nixon and below Marble Bluff Dam near Nixon (sites 21 and 22, table 7) were estimated from data collected at the USGS streamflow-gaging station near Nixon (site 20). Discharge measurements also could not be made at Boca Bridge near Truckee (site 6, table 9); streamflow was estimated from data collected at nearby USGS gaging stations.

Variations in discharge between sites are mostly the result of diversions and tributaries between sites. In particular, the drop in discharge between the sites below Tracy and below Derby Dam near Wadsworth (sites 16 and 17, tables 3 and 6) is mostly flow being diverted to the Truckee Canal. The increase in discharge between the sites below Derby Dam near Wadsworth and at Wadsworth (sites 17 and 18, table 3) is largely due to releases from the Truckee Canal within this reach. The decrease in discharge between the sites at Farad and at Bridge Street bridge at Verdi (sites 7 and 8, table 9) is due in large part to a diversion for hydropower, which returns the water above the site near Mogul (site 9, table 9).

As the dye travels downstream, the concentration is reduced from its peak and the dye plume takes longer to pass each site. For example, during high-flow conditions on the reach between Mogul and Vista (table 2), the peak concentrations at the site above West McCarran Boulevard bridge (site 10) was $23.0 \mu \mathrm{g} / \mathrm{L}$; at Reno (site 11 ), $15.0 \mu \mathrm{g} / \mathrm{L}$; and at Vista (site 13), $8.5 \mu \mathrm{g} / \mathrm{L}$. For each sampling site, the amount of time that the dye concentration was greater than 10 percent of the peak concentration was about 40 minutes at the site above West McCarran Boulevard bridge, about 50 minutes at Reno, and about 1 hour and 15 minutes at Vista. The other dye-study reaches show a similar pattern.

Because the dye plume moved more slowly during medium-flow than during high-flow conditions, it took longer for the dye to pass each site. As an example of such traveltime characteristics, during high-flow conditions, the elapsed time for the dye to travel from the injection point near Mogul (site 9) to its peak concentration at Vista (site 13, table 2) was about 5 hours; during medium-flow conditions, traveltime for the same reach was about 11 hours (table 5). For each sampling site, the amount of time that the dye concentration was greater than 10 percent of the peak concentration was about 1 hour and 10 minutes at the site above West McCarran Boulevard bridge (site 10), about 2 hours at Reno (site 11) and 2 hours and 50 minutes at Vista. A comparison of the medium- and high-flow traveltimes for the reach between Steamboat Creek mouth near 
Sparks and Wadsworth (tables 3 and 6) and for the reach between Wadsworth and Marble Bluff Dam (tables 4 and 7) show similar patterns.

\section{SUMMARY}

In 1999, eight dye-tracing studies were done during two flow regimes on the Truckee River between Tahoe City, Calif., and Marble Bluff Dam near Nixon, Nev. (approximately $3 \mathrm{mi}$ upstream from Pyramid Lake). Three studies were made during high flow, (greater than $2,000 \mathrm{ft}^{3} / \mathrm{s}$ ), and five studies were made during medium flow (173 to $627 \mathrm{ft}^{3} / \mathrm{s}$ ). The high-flow studies were done during April and May, and the medium-flow studies were done during August and September.

The five Truckee River reaches studied were from Tahoe City, Calif., to Boca Bridge near Truckee, Calif.; from the old U.S. Highway 40 bridge near Truckee, Calif., to Mogul, Nev.; from Mogul, Nev., to Vista, Nev.; from Steamboat Creek at its mouth near Sparks, Nev., to Wadsworth, Nev.; and from Wadsworth, Nev., to Marble Bluff Dam near Nixon, Nev.

The results document the traveltime characteristics of the dye plume at each of the sampling points within each study reach. As the dye moved downstream, the peak concentration was reduced and the dye plume increased in length. During medium-flow conditions, the dye took longer to pass each site and traveled more slowly than during high-flow conditions.

\section{REFERENCES CITED}

Bohman, L.R., 2000, Estimation of traveltime characteristics for Truckee River between Truckee, California, and Marble Bluff Dam near Nixon, Nevada, and for Truckee Canal in Nevada: U.S. Geological Survey WaterResources Investigations Report 99-4226, 53 p.

Brown, W.M., III, Nowlin, J.O., Smith, L.H., and Flint, M.R., 1986, River-quality assessment of the Truckee and Carson River system, California and NevadaHydrologic characteristics: U.S. Geological Survey Open-File Report 84-576, 201 p.
Buchanan, T.J., 1964, Time of travel of soluble contaminants in streams: American Society of Civil Engineers Proceedings, Journal of the Hydraulics Division, v. 90, no. SA3, p. 1-12.

Caupp, C.L., Brock, J.T., and Runke, H.M., 1997, Application of the dynamic stream simulation and assessment model (DSSAMt) to the Truckee River below Reno, Nevada-Model formulation and overview: Boise, Idaho, Rapid Creek Research Technical Report No. RCR96-1.1, 107 p.

Jones, Jeanine, Maxwell, S.R., and Hayward, Patricia, 1991, Truckee River atlas: California Department of Water Resources, $128 \mathrm{p}$.

Kilpatrick, F.A., and Wilson, JF., Jr., 1989, Measurement of time of travel in streams by dye tracing: U.S. Geological Survey Techniques of Water-Resources Investigations, bk. 3, chap. A9, 27 p.

La Camera, R.J., Hoffman, R.J., Nowlin, J.O., Smith, L.H., and Lima, S.M., 1985, Data on surface-water quality and quantity, Truckee River system, Nevada and California, 1979-81: U.S. Geological Survey Open-File Report 84-238, $191 \mathrm{p}$.

Nowlin, J.O., 1987, Modeling nutrient and dissolved-oxygen transport in the Truckee River and Truckee Canal downstream from Reno, Nevada: U.S. Geological Survey Water-Resources Investigations Report 87-4037, $487 \mathrm{p}$.

Nowlin, J.O., Brown, W.M., III, Smith, L.H., and Hoffman, R.J., 1980, Planning and design of studies for riverquality assessment in the Truckee and Carson River Basins, California and Nevada: U.S. Geological Survey Open-File Report 80-435, 75 p.

Van Denburgh, A.S., Lamke, R.D., and Hughes, J.L., 1973, A brief water-resources appraisal of the Truckee River Basin, western Nevada: Nevada Division of Water Resources Reconnaissance Report 57, 122 p.

Wilson, J.F., Jr., 1968, Time-of-travel measurements and other applications of dye tracing, in International Union of Geodesy and Geophysics Commission of Surface Waters, Hydrological aspects of the utilization of water: International Association of Scientific Hydrology Publication 76, p. 252-265.

Wilson, JF., Jr., Cobb, E.D., and Kilpatrick, F.A., 1986, Fluorometric procedures for dye tracing: U.S. Geological Survey Techniques of Water-Resources Investigations, bk. 3, chap. A12, 41 p. 
Table 2. Dye-concentration data from traveltime study on Truckee River between Mogul, Nev., and Vista, Nev., May 4, 1999

\begin{tabular}{|c|c|c|c|c|c|c|}
\hline \multicolumn{7}{|l|}{ Sampling site: } \\
\hline Name & \multicolumn{2}{|c|}{$\begin{array}{l}\text { Truckee River } \\
\text { above West McCarran } \\
\text { Boulevard bridge } \\
\text { at Reno, Nev. }\end{array}$} & \multicolumn{2}{|c|}{$\begin{array}{l}\text { Truckee River } \\
\text { at Reno, Nev. }\end{array}$} & \multicolumn{2}{|c|}{$\begin{array}{l}\text { Truckee River } \\
\text { at Vista, Nev. }\end{array}$} \\
\hline Number & \multicolumn{2}{|c|}{10} & \multicolumn{2}{|c|}{11} & \multicolumn{2}{|c|}{13} \\
\hline $\begin{array}{l}\text { Distance down- } \\
\text { stream from } \\
\text { injection site, } \\
\text { in river miles. }\end{array}$ & \multicolumn{2}{|c|}{4.77} & \multicolumn{2}{|c|}{9.67} & \multicolumn{2}{|c|}{15.36} \\
\hline $\begin{array}{l}\text { Streamflow during } \\
\text { sampling period, } \\
\text { in cubic feet per } \\
\text { second. }\end{array}$ & \multicolumn{2}{|c|}{12,300} & \multicolumn{2}{|c|}{2,130} & \multicolumn{2}{|c|}{2,350} \\
\hline \multirow[t]{24}{*}{ Date } & \multicolumn{2}{|c|}{ May 4, 1999} & \multicolumn{2}{|c|}{ May 4, 1999} & \multicolumn{2}{|c|}{ May 4, 1999} \\
\hline & \multicolumn{6}{|c|}{ Rhodamlne WT dye, in mlcrograms per liter } \\
\hline & $\begin{array}{l}\text { Time } \\
\text { of day }\end{array}$ & $\begin{array}{c}\text { Concen- } \\
\text { tration }\end{array}$ & $\begin{array}{c}\text { Time of } \\
\text { day }\end{array}$ & $\begin{array}{l}\text { Concen- } \\
\text { tration }\end{array}$ & $\begin{array}{c}\text { Time of } \\
\text { day }\end{array}$ & $\begin{array}{c}\text { Concen- } \\
\text { tration }\end{array}$ \\
\hline & 1010 & 0.03 & 1124 & ${ }^{1} 0.0$ & 1320 & 0.04 \\
\hline & 1015 & 1.5 & 1130 & .62 & 1330 & .28 \\
\hline & 1017 & 4.9 & 1135 & 1.0 & 1335 & 1.2 \\
\hline & 1019 & 9.4 & 1137 & 2.7 & 1340 & 2.3 \\
\hline & 1021 & 14 & 1139 & 4.1 & 1345 & 4.0 \\
\hline & 1023 & 18 & 1142 & 8.0 & 1350 & 6.4 \\
\hline & 1025 & 21 & 1145 & 12 & 1355 & 7.1 \\
\hline & 1027 & 23 & 1148 & 13 & 1400 & 8.5 \\
\hline & 1029 & 21 & 1151 & 15 & 1405 & 7.3 \\
\hline & 1031 & 20 & 1154 & 15 & 1410 & 7.0 \\
\hline & 1033 & 16 & 1157 & 14 & 1415 & 5.4 \\
\hline & 1035 & 14 & 1200 & 12 & 1420 & 4.2 \\
\hline & 1038 & 8.9 & 1203 & 11 & 1425 & 3.1 \\
\hline & 1041 & 6.5 & 1208 & 5.7 & 1430 & 2.2 \\
\hline & 1044 & 4.2 & 1213 & 4.2 & 1435 & 1.5 \\
\hline & 1047 & 2.8 & 1218 & 2.7 & 1440 & I. .1 \\
\hline & 1050 & 1.6 & 1223 & 1.8 & 1445 & .70 \\
\hline & 1057 & .60 & 1228 & 1.0 & 1450 & .48 \\
\hline & 1100 & .35 & 1233 & .58 & 1455 & .35 \\
\hline & & & 1238 & .38 & 1500 & .23 \\
\hline & & & 1243 & .23 & & \\
\hline
\end{tabular}

${ }^{1}$ Estimated. 
Table 3. Dye-concentration data from traveltime study on Truckee River between Steamboat Creek at mouth near Sparks, Nev., and Wadsworth, Nev., April 30-May 1, 1999

Injection site: Truckee River at Steamboat Creek at mouth near Sparks, Nev. (site number 12)

Date and time of injection: April 30, 1999, at 1025

Volume of injected dye, in liters: 10.2

\begin{tabular}{|c|c|c|c|c|c|c|c|c|}
\hline \multicolumn{9}{|l|}{ Sampling site: } \\
\hline Name & \multicolumn{2}{|c|}{$\begin{array}{l}\text { Truckee River } \\
\text { at Patrick, Nev. }\end{array}$} & \multicolumn{2}{|c|}{$\begin{array}{l}\text { Truckee River } \\
\text { below Tracy }^{1}\end{array}$} & \multicolumn{2}{|c|}{$\begin{array}{c}\text { Truckee River } \\
\text { below Derby Dam } \\
\text { near Wadsworth, Nev. }\end{array}$} & \multicolumn{2}{|c|}{$\begin{array}{c}\text { Truckee River } \\
\text { at Wadsworth, Nev. }\end{array}$} \\
\hline Number & \multicolumn{2}{|c|}{14} & \multicolumn{2}{|c|}{16} & \multicolumn{2}{|c|}{17} & \multicolumn{2}{|c|}{18} \\
\hline $\begin{array}{l}\text { Distance down- } \\
\text { stream from } \\
\text { injection site, } \\
\text { in river miles. }\end{array}$ & \multicolumn{2}{|c|}{8.61} & \multicolumn{2}{|c|}{12.91} & \multicolumn{2}{|c|}{19.04} & \multicolumn{2}{|c|}{29.84} \\
\hline $\begin{array}{l}\text { Streamflow during } \\
\text { sampling period, } \\
\text { in cubic feet per } \\
\text { second. }\end{array}$ & \multicolumn{2}{|c|}{$2_{2,460}$} & \multicolumn{2}{|c|}{22,480} & \multicolumn{2}{|c|}{2,170} & \multicolumn{2}{|c|}{2,500} \\
\hline \multirow[t]{30}{*}{ Date } & \multicolumn{2}{|c|}{ April 30, 1999} & \multicolumn{2}{|c|}{ April 30, 1999} & \multicolumn{2}{|c|}{ April 30, 1999} & \multicolumn{2}{|c|}{ April 30-May 1, 1999} \\
\hline & \multicolumn{8}{|c|}{ Rhodamine WT dye, in micrograms per liter } \\
\hline & $\begin{array}{l}\text { Time } \\
\text { of day }\end{array}$ & $\begin{array}{c}\text { Concen- } \\
\text { tration }\end{array}$ & $\begin{array}{l}\text { Time } \\
\text { of day }\end{array}$ & $\begin{array}{l}\text { Concen- } \\
\text { tration }\end{array}$ & $\begin{array}{c}\text { Time of } \\
\text { day }\end{array}$ & $\begin{array}{c}\text { Concen- } \\
\text { tration }\end{array}$ & $\begin{array}{l}\text { Time } \\
\text { of day }\end{array}$ & $\begin{array}{l}\text { Concen- } \\
\text { tration }\end{array}$ \\
\hline & 1255 & 0.02 & 1500 & 0.04 & 1700 & 0.02 & 1945 & 0.02 \\
\hline & 1305 & .04 & 1515 & 2.0 & 1715 & .03 & 2000 & .03 \\
\hline & 1315 & .03 & 1520 & 4.2 & 1730 & .12 & 2015 & .04 \\
\hline & 1325 & .58 & 1530 & 8.1 & 1745 & 1.5 & 2030 & .04 \\
\hline & 1335 & 5.6 & 1535 & 8.4 & 1755 & 1.5 & 2050 & .04 \\
\hline & 1340 & 9.0 & 1540 & 10 & 1805 & 2.6 & 2110 & .23 \\
\hline & 1345 & 11 & 1545 & 10 & 1815 & 3.4 & 2130 & 1.4 \\
\hline & 1350 & 12 & 1550 & 9.8 & 1820 & 3.7 & 2150 & 2.1 \\
\hline & 1355 & 11 & 1555 & 7.4 & 1825 & 3.8 & 2210 & 3.0 \\
\hline & 1400 & 9.2 & 1605 & 5.5 & 1830 & 3.8 & 2230 & 2.4 \\
\hline & 1405 & 7.6 & 1615 & 3.0 & 1835 & 3.6 & 2250 & 2.0 \\
\hline & 1410 & 5.1 & 1625 & 1.7 & 1840 & 3.4 & 2310 & 1.4 \\
\hline & 1415 & 3.6 & 1635 & .75 & 1850 & 2.8 & 2330 & 1.1 \\
\hline & 1420 & 2.6 & 1645 & .42 & 1900 & 2.3 & 2350 & .85 \\
\hline & 1425 & 1.8 & 1655 & .21 & 1910 & 2.1 & 0010 & .76 \\
\hline & 1435 & .75 & & & 1920 & 1.7 & 0030 & .62 \\
\hline & 1445 & .37 & & & 1930 & 1.4 & 0050 & .60 \\
\hline & 1455 & .20 & & & 1940 & 1.2 & 0110 & .44 \\
\hline & 1505 & .15 & & & 1950 & 1.0 & 0207 & ${ }^{2} .2$ \\
\hline & 1515 & .10 & & & 2000 & .86 & & \\
\hline & & & & & 2015 & .75 & & \\
\hline & & & & & 2030 & .66 & & \\
\hline & & & & & 2045 & .64 & & \\
\hline & & & & & 2100 & .54 & & \\
\hline & & & & & 2120 & .40 & & \\
\hline & & & & & 2140 & .39 & & \\
\hline & & & & & 2219 & ${ }^{2} .2$ & & \\
\hline
\end{tabular}

${ }^{1}$ Powerplant near Tracy, Nev.

${ }^{2}$ Estimated. 
Table 4. Dye-concentration data from traveltime study on Truckee River between Wadsworth, Nev., and Marble Bluff Dam near Nixon, Nev., April 28, 1999

\begin{tabular}{|c|c|c|c|c|c|c|}
\hline \multicolumn{7}{|l|}{ Sampling site: } \\
\hline Name & \multicolumn{2}{|c|}{$\begin{array}{l}\text { Truckee River } \\
\text { at Dead Ox Wash } \\
\text { near Nixon, Nev. }\end{array}$} & \multicolumn{2}{|c|}{$\begin{array}{c}\text { Truckee River } \\
\text { at State Highway } 447 \\
\text { at Nixon, Nev. }\end{array}$} & \multicolumn{2}{|c|}{$\begin{array}{c}\text { Truckee River } \\
\text { below Marble Bluff Dam }\end{array}$} \\
\hline Number & \multicolumn{2}{|c|}{19} & \multicolumn{2}{|c|}{21} & \multicolumn{2}{|c|}{22} \\
\hline $\begin{array}{l}\text { Distance down- } \\
\text { stream from } \\
\text { injection site, } \\
\text { in river miles. }\end{array}$ & \multicolumn{2}{|c|}{10.51} & \multicolumn{2}{|c|}{20.47} & \multicolumn{2}{|c|}{23.74} \\
\hline $\begin{array}{l}\text { Streamflow during } \\
\text { sampling period, } \\
\text { in cubic feet per } \\
\text { second. }\end{array}$ & \multicolumn{2}{|c|}{2,780} & \multicolumn{2}{|c|}{2,720} & \multicolumn{2}{|c|}{2,720} \\
\hline \multirow[t]{23}{*}{ Date } & \multicolumn{2}{|c|}{ April 28, 1999} & \multicolumn{2}{|c|}{ April 28, 1999} & \multicolumn{2}{|c|}{ April 28, 1999} \\
\hline & \multicolumn{6}{|c|}{ Rhodamine WT dye, in micrograms per liter } \\
\hline & $\begin{array}{l}\text { Time } \\
\text { of day }\end{array}$ & $\begin{array}{l}\text { Concen- } \\
\text { tration }\end{array}$ & $\begin{array}{c}\text { Time of } \\
\text { day }\end{array}$ & $\begin{array}{l}\text { Concen- } \\
\text { tration }\end{array}$ & $\begin{array}{c}\text { Time of } \\
\text { day }\end{array}$ & $\begin{array}{l}\text { Concen- } \\
\text { tration }\end{array}$ \\
\hline & 1225 & 0.13 & 1535 & 0.09 & 1716 & ${ }^{2} 0$ \\
\hline & 1247 & 4.2 & 1550 & .95 & 1755 & 6.1 \\
\hline & 1257 & 7.4 & 1605 & 1.1 & 1815 & 5.0 \\
\hline & 1307 & 10 & 1620 & 4.0 & 1835 & 3.1 \\
\hline & 1317 & 9.2 & 1635 & 6.6 & 1855 & 1.6 \\
\hline & 1327 & 7.8 & 1650 & 7.0 & 1915 & 1.1 \\
\hline & 1337 & 5.5 & 1705 & 5.5 & 1935 & .66 \\
\hline & 1347 & 3.4 & 1720 & 3.6 & 1955 & .35 \\
\hline & 1357 & 2.2 & 1735 & 2.2 & 2015 & .28 \\
\hline & 1407 & 1.7 & 1750 & 1.5 & 2035 & .24 \\
\hline & 1417 & 1.1 & 1805 & .88 & 2055 & .19 \\
\hline & 1427 & .83 & 1820 & .60 & 2115 & .17 \\
\hline & 1437 & .53 & 1835 & .37 & 2135 & .17 \\
\hline & 1447 & .45 & 1850 & .27 & 2155 & .18 \\
\hline & 1457 & .34 & 1905 & .23 & 2215 & .09 \\
\hline & 1507 & .26 & 1935 & .14 & 2235 & .10 \\
\hline & 1516 & ${ }^{2} .2$ & 1950 & .12 & 2255 & .11 \\
\hline & & & & & 2315 & .09 \\
\hline & & & & & 2335 & .09 \\
\hline & & & & & 2345 & .08 \\
\hline
\end{tabular}

${ }^{1}$ Near Nixon, Nev.

${ }^{2}$ Estimated. 
Table 5. Dye-concentration data from traveltime study on Truckee River between Mogul, Nev., and Vista, Nev., August 25, 1999

Injection site: Truckee River near Mogul, Nev. (site number 9)

Date and time of injection: August 25, 1999, at 0815

Volume of injected dye, in liters: 2.65

\begin{tabular}{|c|c|c|c|c|c|c|}
\hline \multicolumn{7}{|l|}{ Sampling site: } \\
\hline Name & \multicolumn{2}{|c|}{$\begin{array}{l}\text { Truckee River } \\
\text { above West McCarran } \\
\text { Boulevard bridge } \\
\text { at Reno, Nev. }\end{array}$} & \multicolumn{2}{|c|}{$\begin{array}{l}\text { Truckee River } \\
\text { at Reno, Nev. }\end{array}$} & \multicolumn{2}{|c|}{$\begin{array}{l}\text { Truckee River } \\
\text { at Vista, Nev. }\end{array}$} \\
\hline Number & \multicolumn{2}{|c|}{10} & \multicolumn{2}{|c|}{11} & \multicolumn{2}{|c|}{13} \\
\hline $\begin{array}{l}\text { Distance down- } \\
\text { stream from } \\
\text { injection site, } \\
\text { in river miles. }\end{array}$ & \multicolumn{2}{|c|}{4.77} & \multicolumn{2}{|c|}{9.67} & \multicolumn{2}{|c|}{15.36} \\
\hline $\begin{array}{l}\text { Streamflow during } \\
\text { sampling period, } \\
\text { in cubic feet per } \\
\text { second. }\end{array}$ & \multicolumn{2}{|c|}{432} & \multicolumn{2}{|c|}{417} & \multicolumn{2}{|c|}{490} \\
\hline \multirow[t]{25}{*}{ Date } & \multicolumn{2}{|c|}{ August 25, 1999} & \multicolumn{2}{|c|}{ August 25, 1999} & \multicolumn{2}{|c|}{ August 25, 1999} \\
\hline & \multicolumn{6}{|c|}{ Rhodamine WT dye, in mlcrograms per liter } \\
\hline & $\begin{array}{l}\text { Time } \\
\text { of day }\end{array}$ & $\begin{array}{c}\text { Concen- } \\
\text { tration }\end{array}$ & $\begin{array}{c}\text { Time of } \\
\text { day }\end{array}$ & $\begin{array}{c}\text { Concen- } \\
\text { tration }\end{array}$ & $\begin{array}{c}\text { Time of } \\
\text { day }\end{array}$ & $\begin{array}{c}\text { Concen- } \\
\text { tration }\end{array}$ \\
\hline & 1040 & 0.02 & 1307 & 0.05 & 1728 & 0.04 \\
\hline & 1052 & 2.3 & 1317 & .07 & 1745 & .06 \\
\hline & 1057 & 5.4 & 1327 & .50 & 1800 & .23 \\
\hline & 1102 & 10 & 1332 & 1.2 & 1809 & .38 \\
\hline & 1107 & 12 & 1339 & 2.4 & 1820 & .78 \\
\hline & 1112 & 14 & 1246 & 4.1 & 1830 & 1.4 \\
\hline & 1117 & 14 & 1352 & 6.1 & 1840 & 2.1 \\
\hline & 1122 & 13 & 1359 & 7.6 & 1850 & 2.8 \\
\hline & 1127 & [1] & 1405 & 8.6 & 1900 & 3.1 \\
\hline & 1137 & 7.2 & 1410 & 9.2 & 1910 & 3.8 \\
\hline & 1147 & 3.4 & 1415 & 9.4 & 1920 & 4.0 \\
\hline & 1157 & 2.0 & 1420 & 9.3 & 1930 & 3.8 \\
\hline & 1207 & 1.0 & 1425 & 8.8 & 1942 & 3.6 \\
\hline & 1217 & .62 & 1430 & 8.0 & 1950 & 3.2 \\
\hline & 1227 & $i_{.2}$ & 1435 & 7.2 & 2000 & 2.8 \\
\hline & & & 1445 & 5.6 & 2010 & 2.5 \\
\hline & & & 1456 & 3.8 & 2020 & 1.9 \\
\hline & & & 1506 & 2.8 & 2041 & 1.4 \\
\hline & & & 1521 & 1.4 & 2100 & .78 \\
\hline & & & 1532 & .94 & 2120 & .44 \\
\hline & & & 1542 & .62 & 2140 & .25 \\
\hline & & & 1557 & ${ }^{1} .2$ & & \\
\hline
\end{tabular}

${ }^{\mathbf{J}}$ Estimated. 
Table 6. Dye-concentration data from traveltime study on Truckee River between Steamboat Creek at mouth near Sparks, Nev., and Wadsworth, Nev., August 18-20, 1999

\begin{tabular}{|c|c|c|c|c|c|c|c|c|}
\hline \multicolumn{9}{|l|}{ Sampling site: } \\
\hline Name & \multicolumn{2}{|c|}{$\begin{array}{l}\text { Truckee River } \\
\text { at Patrick, Nev. }\end{array}$} & \multicolumn{2}{|c|}{$\begin{array}{l}\text { Truckee River } \\
\text { below Tracy }\end{array}$} & \multicolumn{2}{|c|}{$\begin{array}{l}\text { Truckee River } \\
\text { below Derby Dam near } \\
\text { Wadsworth, Nev. }\end{array}$} & \multicolumn{2}{|c|}{$\begin{array}{c}\text { Truckee River } \\
\text { at Wadsworth, Nev. }\end{array}$} \\
\hline Number & \multicolumn{2}{|c|}{14} & \multicolumn{2}{|c|}{16} & \multicolumn{2}{|c|}{17} & \multicolumn{2}{|c|}{18} \\
\hline $\begin{array}{l}\text { Distance down- } \\
\text { stream from } \\
\text { injection site, } \\
\text { in river miles. }\end{array}$ & \multicolumn{2}{|c|}{8.61} & \multicolumn{2}{|c|}{12.91} & \multicolumn{2}{|c|}{19.04} & \multicolumn{2}{|c|}{29.84} \\
\hline $\begin{array}{l}\text { Streamflow during } \\
\text { sampling period, } \\
\text { in cubic feet per } \\
\text { second. }\end{array}$ & \multicolumn{2}{|c|}{${ }^{2} 570$} & \multicolumn{2}{|c|}{530} & \multicolumn{2}{|c|}{470} & \multicolumn{2}{|c|}{330} \\
\hline \multirow[t]{38}{*}{ Date } & \multicolumn{2}{|c|}{ August 18,1999} & \multicolumn{2}{|c|}{ August 18, 1999} & \multicolumn{2}{|c|}{ August 19, 1999} & \multicolumn{2}{|c|}{ August 19-20, 1999} \\
\hline & \multicolumn{8}{|c|}{ Rhodamine WT dye, in micrograms per llter } \\
\hline & $\begin{array}{l}\text { Time } \\
\text { of day }\end{array}$ & $\begin{array}{c}\text { Concen- } \\
\text { tration }\end{array}$ & $\begin{array}{l}\text { Time } \\
\text { of day }\end{array}$ & $\begin{array}{l}\text { Concen- } \\
\text { tration }\end{array}$ & $\begin{array}{l}\text { Time } \\
\text { of day }\end{array}$ & $\begin{array}{l}\text { Concen- } \\
\text { tration }\end{array}$ & $\begin{array}{l}\text { Time } \\
\text { of day }\end{array}$ & $\begin{array}{c}\text { Concen- } \\
\text { tration }\end{array}$ \\
\hline & 1430 & 0.03 & 1815 & 0.03 & 0015 & 0.03 & 0930 & 0.03 \\
\hline & 1445 & .08 & 1830 & .10 & 0030 & .06 & 1000 & .10 \\
\hline & 1500 & .74 & 1845 & .30 & 0100 & .15 & 1030 & .26 \\
\hline & 1515 & 2.4 & 1900 & .88 & 0115 & .21 & 1045 & .44 \\
\hline & 1530 & 6.0 & 1915 & 2.2 & 0130 & .38 & 1100 & .64 \\
\hline & 1545 & 8.2 & 1930 & 3.6 & 0145 & .62 & 1120 & .90 \\
\hline & 1600 & 10 & 1945 & 5.4 & 0200 & .98 & 1140 & 1.2 \\
\hline & 1615 & 8.8 & 2000 & 6.7 & 0215 & 1.2 & 1200 & 1.4 \\
\hline & 1630 & 8.0 & 2015 & 7.4 & 0230 & 1.6 & 1230 & 1.7 \\
\hline & 1645 & 6.0 & 2030 & 7.0 & 0245 & 2.0 & 1245 & 1.7 \\
\hline & 1700 & 4.4 & 2045 & 6.3 & 0300 & 2.4 & 1300 & 1.7 \\
\hline & 1715 & 3.0 & 2100 & 5.4 & 0315 & 2.3 & 1315 & 1.7 \\
\hline & 1730 & 2.0 & 2115 & 4.2 & 0330 & 2.4 & 1330 & 1.7 \\
\hline & 1745 & 1.2 & 2130 & 3.4 & 0345 & 2.4 & 1350 & 1.6 \\
\hline & 1800 & .82 & 2145 & 2.4 & 0400 & 2.3 & 1410 & 1.5 \\
\hline & 1914 & ${ }^{2} .2$ & 2200 & 1.5 & 0415 & 2.2 & 1440 & 1.3 \\
\hline & & & 2215 & 1.1 & 0430 & 2.1 & 1510 & 1.2 \\
\hline & & & 2230 & .86 & 0445 & 2.0 & 1550 & .98 \\
\hline & & & 2300 & .52 & 0500 & 1.9 & 1650 & .82 \\
\hline & & & 2315 & .36 & 0515 & 1.8 & 1830 & .68 \\
\hline & & & 2344 & ${ }^{2} .2$ & 0530 & 1.6 & 2030 & .52 \\
\hline & & & & & 0545 & 1.4 & 0338 & ${ }^{2} .2$ \\
\hline & & & & & 0615 & 1.2 & 0715 & .12 \\
\hline & & & & & 0630 & 1.0 & & \\
\hline & & & & & 0645 & .96 & & \\
\hline & & & & & 0700 & .94 & & \\
\hline & & & & & 0715 & .87 & & \\
\hline & & & & & 0730 & .80 & & \\
\hline & & & & & 0745 & .74 & & \\
\hline & & & & & 0815 & .70 & & \\
\hline & & & & & 0830 & .66 & & \\
\hline & & & & & 0920 & .58 & & \\
\hline & & & & & 0935 & .54 & & \\
\hline & & & & & 0950 & .53 & & \\
\hline & & & & & 1432 & ${ }^{2} .2$ & & \\
\hline
\end{tabular}

${ }^{1}$ Powerplant near Tracy, Nev.

${ }^{2}$ Estimated. 
Table 7. Dye-concentration data from traveltime study on Truckee River between Wadsworth, Nev., and Marble Bluff Dam near Nixon, Nev., August 16-17, 1999

\begin{tabular}{|c|c|c|c|c|c|c|}
\hline \multicolumn{7}{|l|}{ Sampling site: } \\
\hline Name & \multicolumn{2}{|c|}{$\begin{array}{l}\text { Truckee River } \\
\text { at Dead Ox Wash } \\
\text { near Nixon, Nev. }\end{array}$} & \multicolumn{2}{|c|}{$\begin{array}{c}\text { Truckee River } \\
\text { at State Highway } 447 \\
\text { at Nixon, Nev. }\end{array}$} & \multicolumn{2}{|c|}{$\begin{array}{c}\begin{array}{c}\text { Truckee River } \\
\text { below }\end{array} \\
\text { Marble Bluff Dam } 1\end{array}$} \\
\hline Number & \multicolumn{2}{|c|}{19} & \multicolumn{2}{|c|}{21} & \multicolumn{2}{|c|}{22} \\
\hline $\begin{array}{l}\text { Distance down- } \\
\text { stream from } \\
\text { injection site, } \\
\text { in river miles. }\end{array}$ & \multicolumn{2}{|c|}{10.51} & \multicolumn{2}{|c|}{20.47} & \multicolumn{2}{|c|}{23.74} \\
\hline $\begin{array}{l}\text { Streamflow during } \\
\text { sampling period, } \\
\text { in cubic feet per } \\
\text { second. }\end{array}$ & \multicolumn{2}{|c|}{469} & \multicolumn{2}{|c|}{2425} & \multicolumn{2}{|c|}{2425} \\
\hline \multirow[t]{32}{*}{ Date } & \multicolumn{2}{|c|}{ August 16, 1999} & \multicolumn{2}{|c|}{ August 17, 1999} & \multicolumn{2}{|c|}{ August 17, 1999} \\
\hline & \multicolumn{6}{|c|}{ Rhodamlne WT dye, In mlcrograms per llter } \\
\hline & $\begin{array}{l}\text { Time } \\
\text { of day }\end{array}$ & $\begin{array}{c}\text { Concen- } \\
\text { tration }\end{array}$ & $\begin{array}{l}\text { Time } \\
\text { of day }\end{array}$ & $\begin{array}{l}\text { Concen- } \\
\text { tration }\end{array}$ & $\begin{array}{c}\text { Time of } \\
\text { day }\end{array}$ & $\begin{array}{c}\text { Concen- } \\
\text { tration }\end{array}$ \\
\hline & 1620 & 0.04 & 0145 & 0.04 & 0415 & 0.02 \\
\hline & 1635 & .05 & 0200 & .05 & 0430 & .04 \\
\hline & 1650 & .24 & 0215 & .08 & 0445 & .07 \\
\hline & 1705 & 1.4 & 0230 & .19 & 0500 & .13 \\
\hline & 1720 & 2.8 & 0245 & .40 & 0515 & .27 \\
\hline & 1735 & 4.8 & 0300 & .72 & 0530 & .54 \\
\hline & 1750 & 6.6 & 0315 & 1.3 & 0545 & .96 \\
\hline & 1805 & 7.4 & 0400 & 3.2 & 0600 & 1.5 \\
\hline & 1820 & 7.2 & 0415 & 3.4 & 0615 & 2.1 \\
\hline & 1835 & 6.4 & 0430 & 4.1 & 0630 & 2.6 \\
\hline & 1850 & 5.4 & 0445 & 3.6 & 0645 & 2.9 \\
\hline & 1905 & 3.8 & 0500 & 4.2 & 0700 & 3.4 \\
\hline & 1920 & 3.0 & 0515 & 3.9 & 0715 & 3.8 \\
\hline & 1935 & 2.2 & 0530 & 3.6 & 0730 & 4.0 \\
\hline & 1950 & 1.6 & 0550 & 3.2 & 0745 & 3.8 \\
\hline & 2005 & 1.3 & 0610 & 2.6 & 0800 & 3.7 \\
\hline & 2020 & .98 & 0640 & 1.8 & 0815 & 3.4 \\
\hline & 2035 & .78 & 0710 & 1.3 & 0830 & 3.2 \\
\hline & 2050 & .62 & 0740 & .92 & 0845 & 2.8 \\
\hline & 2144 & ${ }^{2} .2$ & 0810 & .64 & 0900 & 2.5 \\
\hline & & & 0840 & .50 & 0915 & 2.2 \\
\hline & & & 0910 & .34 & 0930 & 1.7 \\
\hline & & & 0938 & ${ }^{2} .2$ & 1000 & 1.0 \\
\hline & & & & & 1030 & .86 \\
\hline & & & & & 1100 & .64 \\
\hline & & & & & 1130 & .48 \\
\hline & & & & & 1200 & .35 \\
\hline & & & & & 1230 & .30 \\
\hline & & & & & 1300 & .22 \\
\hline
\end{tabular}

${ }^{1}$ Near Nixon, Nev,

${ }^{2}$ Estimated. 
Table 8. Dye-concentration data from traveltime study on Truckee River between Tahoe City, Calif., and Boca Bridge near Truckee, Calif, September 14-15, 1999

Injection site: Truckee River at Tahoe City, Calif. (site number 1)

Date and time of injection: September 14, 1999, at 1900

Volume of injected dye, in liters: 2.55

\begin{tabular}{|c|c|c|c|c|c|c|c|c|c|c|}
\hline \multicolumn{11}{|l|}{ Sampling site: } \\
\hline Name & \multicolumn{2}{|c|}{$\begin{array}{c}\text { Truckee River } \\
\text { below Squaw Creek } \\
\text { near Tahoe City, Calif. }\end{array}$} & \multicolumn{2}{|c|}{$\begin{array}{c}\text { Truckee Piver } \\
\text { near Truckee, Calif. }\end{array}$} & \multicolumn{2}{|c|}{$\begin{array}{c}\text { Truckee River } \\
\text { at State Highway } 267 \\
\text { at Truckee, Calif. }\end{array}$} & \multicolumn{2}{|c|}{$\begin{array}{c}\text { Truckee River } \\
\text { above old U.S. } 40 \text { bridge } \\
\text { below Truckee, Calif. }\end{array}$} & \multicolumn{2}{|c|}{$\begin{array}{l}\text { Truckee River } \\
\text { at Boca Bridge near } \\
\text { Truckee, Calif. }\end{array}$} \\
\hline Number & \multicolumn{2}{|c|}{2} & \multicolumn{2}{|c|}{3} & \multicolumn{2}{|c|}{4} & \multicolumn{2}{|c|}{5} & \multicolumn{2}{|c|}{6} \\
\hline $\begin{array}{l}\text { Distance down- } \\
\text { stream from } \\
\text { injection site, } \\
\text { in river miles. }\end{array}$ & \multicolumn{2}{|c|}{6.15} & \multicolumn{2}{|c|}{12.63} & \multicolumn{2}{|c|}{15.39} & \multicolumn{2}{|c|}{20.08} & \multicolumn{2}{|c|}{25.01} \\
\hline $\begin{array}{l}\text { Streamflow during } \\
\text { sampling period, } \\
\text { in cubic feet per } \\
\text { second. }\end{array}$ & \multicolumn{2}{|c|}{1263} & \multicolumn{2}{|c|}{266} & \multicolumn{2}{|c|}{${ }^{1} 320$} & \multicolumn{2}{|c|}{346} & \multicolumn{2}{|c|}{570} \\
\hline \multirow[t]{29}{*}{ Date } & \multicolumn{2}{|c|}{ September 14-15, 1999} & \multicolumn{2}{|c|}{ September 15, 1999} & \multicolumn{2}{|c|}{ September 15, 1999} & \multicolumn{2}{|c|}{ September 15, 1999} & \multicolumn{2}{|c|}{ September 15, 1999} \\
\hline & & & & Rho & e WT dy & microgran & er liter & & & \\
\hline & $\begin{array}{l}\text { Time } \\
\text { of day }\end{array}$ & $\begin{array}{c}\text { Concen- } \\
\text { tration }\end{array}$ & $\begin{array}{l}\text { Time } \\
\text { of day }\end{array}$ & $\begin{array}{l}\text { Concen- } \\
\text { tration }\end{array}$ & $\begin{array}{l}\text { Time } \\
\text { of day }\end{array}$ & $\begin{array}{l}\text { Concen- } \\
\text { tration }\end{array}$ & $\begin{array}{l}\text { Time } \\
\text { of day }\end{array}$ & $\begin{array}{l}\text { Concen- } \\
\text { tration }\end{array}$ & $\begin{array}{l}\text { Time } \\
\text { of day }\end{array}$ & $\begin{array}{c}\text { Concen- } \\
\text { tration }\end{array}$ \\
\hline & 2315 & 0.03 & 0318 & ${ }^{1} 0.0$ & 0450 & 0.03 & 0759 & .02 & 1115 & 0.03 \\
\hline & 2330 & .79 & 0325 & 1.0 & 0510 & .38 & 0812 & .19 & 1130 & .08 \\
\hline & 2340 & 2.5 & 0335 & 2.6 & 0530 & 1.8 & 0826 & .32 & 1145 & .40 \\
\hline & 2350 & 5.2 & 0355 & 5.9 & 0545 & 3.8 & 0837 & .77 & 1200 & .54 \\
\hline & 2400 & 8.3 & 0405 & 7.4 & 0555 & 5.1 & 0851 & 1.7 & 1215 & .95 \\
\hline & 0010 & 10 & 0417 & 8.6 & 0605 & 6.2 & 0905 & 2.8 & 1230 & 1.4 \\
\hline & 0020 & 11 & 0421 & 8.8 & 0615 & 6.6 & 0910 & 3.7 & 1245 & 1.7 \\
\hline & 0030 & 11 & 0427 & 8.9 & 0625 & 7.0 & 0925 & 4.1 & 1300 & 1.9 \\
\hline & 0040 & 10 & 0432 & 8.8 & 0635 & 7.0 & 0935 & 5.2 & 1315 & 2.0 \\
\hline & 0055 & 7.9 & 0442 & 7.8 & 0645 & 6.6 & 0943 & 5.4 & 1330 & 1.8 \\
\hline & 0115 & 5.4 & 0453 & 7.2 & 0655 & 6.0 & 0953 & 5.5 & 1345 & 1.5 \\
\hline & 0140 & 3.0 & 0505 & 5.8 & 0705 & 5.2 & 1002 & 5.4 & 1400 & 1.2 \\
\hline & 0200 & 1.8 & 0515 & 4.8 & 0715 & 4.3 & 1012 & 5.1 & 1415 & .99 \\
\hline & 0221 & 1.2 & 0530 & 3.7 & 0730 & 3.2 & 1021 & 4.6 & 1430 & .78 \\
\hline & 0241 & .76 & 0545 & 2.6 & 0745 & 2.3 & 1031 & 4.1 & 1445 & .59 \\
\hline & 0324 & ${ }^{1} .2$ & 0600 & 1.7 & 0800 & 1.8 & 1041 & 3.7 & 1500 & .44 \\
\hline & & & 0615 & 1.4 & 0815 & 1.3 & 1051 & 3.1 & 1515 & .35 \\
\hline & & & 0630 & 1.1 & 0830 & 1.0 & 1106 & 2.4 & 1530 & .27 \\
\hline & & & 0646 & .74 & 0845 & .73 & 1121 & 1.7 & 1545 & .24 \\
\hline & & & 0700 & .60 & 0900 & .58 & 1136 & 1.3 & 1600 & .20 \\
\hline & & & 0742 & ${ }^{1} .2$ & 0948 & 1.2 & 1151 & 1.0 & 1615 & .16 \\
\hline & & & & & & & 1206 & .78 & 1630 & .14 \\
\hline & & & & & & & 1221 & .58 & & \\
\hline & & & & & & & 1236 & .50 & & \\
\hline & & & & & & & 1251 & .39 & & \\
\hline & & & & & & & 1330 & ${ }^{1} .2$ & & \\
\hline
\end{tabular}

${ }^{1}$ Estimated. 
Table 9. Dye-concentration data from traveltime study on Truckee River between old U.S. Highway 40 bridge near Truckee, Calif., and Mogul, Nev., September 19-20, 1999

\begin{tabular}{|c|c|c|c|c|c|c|c|c|}
\hline \multicolumn{9}{|l|}{ Sampling site: } \\
\hline Name & \multicolumn{2}{|c|}{$\begin{array}{l}\text { Truckee River } \\
\text { at Boca Bridge near } \\
\text { Truckee, Calif. }\end{array}$} & \multicolumn{2}{|c|}{$\begin{array}{l}\text { Truckee River } \\
\text { at Farad }\end{array}$} & \multicolumn{2}{|c|}{$\begin{array}{c}\text { Truckee River } \\
\text { at Bridge Street } \\
\text { bridge at Verdi, Nev. }\end{array}$} & \multicolumn{2}{|c|}{$\begin{array}{c}\text { Truckee River } \\
\text { near Mogul, Nev. }\end{array}$} \\
\hline Number & \multicolumn{2}{|c|}{6} & \multicolumn{2}{|c|}{7} & \multicolumn{2}{|c|}{8} & \multicolumn{2}{|c|}{9} \\
\hline $\begin{array}{l}\text { Distance down- } \\
\text { stream from } \\
\text { injection site, } \\
\text { in river miles. }\end{array}$ & \multicolumn{2}{|c|}{4.90} & \multicolumn{2}{|c|}{14.25} & \multicolumn{2}{|c|}{22.64} & \multicolumn{2}{|c|}{27.40} \\
\hline $\begin{array}{l}\text { Streamflow during } \\
\text { sampling period, } \\
\text { in cubic feet per } \\
\text { second. }\end{array}$ & \multicolumn{2}{|c|}{${ }^{2} 627$} & \multicolumn{2}{|c|}{627} & \multicolumn{2}{|c|}{$173^{3}$} & \multicolumn{2}{|c|}{505} \\
\hline \multirow[t]{23}{*}{ Date } & \multicolumn{2}{|c|}{ September 20, 1999} & \multicolumn{2}{|c|}{ September 20, 1999} & \multicolumn{2}{|c|}{ September 20, 1999} & \multicolumn{2}{|c|}{ September 20, 1999} \\
\hline & \multicolumn{8}{|c|}{ Rhodamlne WT dye, in micrograms per iiter } \\
\hline & $\begin{array}{l}\text { Time } \\
\text { of day }\end{array}$ & $\begin{array}{c}\text { Concen- } \\
\text { tration }\end{array}$ & $\begin{array}{l}\text { Time } \\
\text { of day }\end{array}$ & $\begin{array}{c}\text { Concen- } \\
\text { tration }\end{array}$ & $\begin{array}{l}\text { Time } \\
\text { of day }\end{array}$ & $\begin{array}{l}\text { Concen- } \\
\text { tration }\end{array}$ & $\begin{array}{l}\text { Time } \\
\text { of Day }\end{array}$ & $\begin{array}{c}\text { Concen- } \\
\text { tration }\end{array}$ \\
\hline & 0100 & 0.05 & 0650 & 0.03 & 1215 & 0.03 & 1500 & 0.10 \\
\hline & 0130 & .02 & 0714 & .10 & 1230 & .06 & 1520 & .20 \\
\hline & 0200 & .04 & 0744 & 1.4 & 1245 & .05 & 1540 & .21 \\
\hline & 0230 & 2.2 & 0750 & 1.8 & 1300 & .15 & 1605 & .40 \\
\hline & 0240 & 4.2 & 0755 & 2.4 & 1315 & .40 & 1621 & .45 \\
\hline & 0248 & 4.2 & 0800 & 2.6 & 1330 & .80 & 1643 & .50 \\
\hline & 0250 & 4.0 & 0805 & 2.8 & 1345 & 1.3 & 1701 & .70 \\
\hline & 0255 & 3.4 & 0810 & 3.0 & 1400 & 1.7 & 1722 & .85 \\
\hline & 0300 & 2.8 & 0815 & 2.6 & 1415 & 1.8 & 1742 & .75 \\
\hline & 0305 & 2.2 & 0821 & 2.8 & 1430 & 1.6 & 1804 & .72 \\
\hline & 0310 & 1.8 & 0827 & 2.6 & 1445 & 1.3 & 1824 & .58 \\
\hline & 0315 & 1.1 & 0835 & 2.2 & 1500 & 1.0 & 1845 & .50 \\
\hline & 0320 & 1.0 & 0850 & 1.4 & 1515 & .70 & 1904 & .40 \\
\hline & 0325 & .60 & 0913 & .60 & 1530 & .50 & 1922 & .40 \\
\hline & 0330 & .60 & 0933 & .30 & 1545 & .35 & 1942 & .35 \\
\hline & 0335 & .40 & 0940 & .20 & 1600 & .20 & 2003 & .31 \\
\hline & 0340 & .30 & & & 1615 & .15 & 2022 & .20 \\
\hline & 0345 & .20 & & & 1630 & .10 & 2043 & .20 \\
\hline & 0350 & .09 & & & 1645 & .08 & 2104 & .10 \\
\hline & & & & & 1700 & .05 & 2133 & .10 \\
\hline
\end{tabular}

\footnotetext{
${ }^{1}$ Powerplant near Floriston, Calif.

${ }^{2}$ Estimated.

${ }^{3}$ Part of flow directed upstream of site for hydropower.
} 


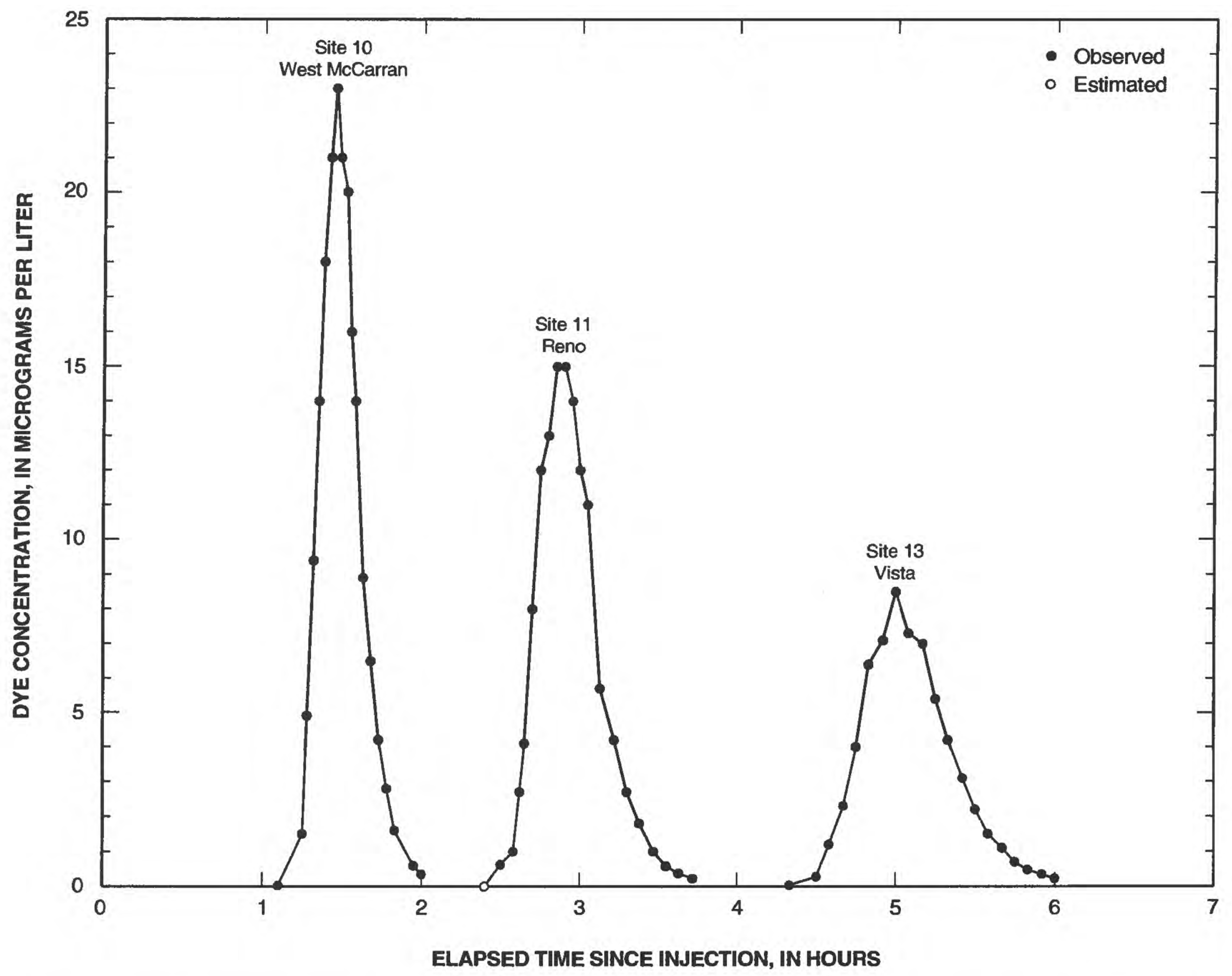

Figure 2. Observed response curves for Truckee River sites, 10, 11, and 13 for reach between Mogul, Nev., and Vista, Nev., May 4, 1999. See table 1 for full site names. 


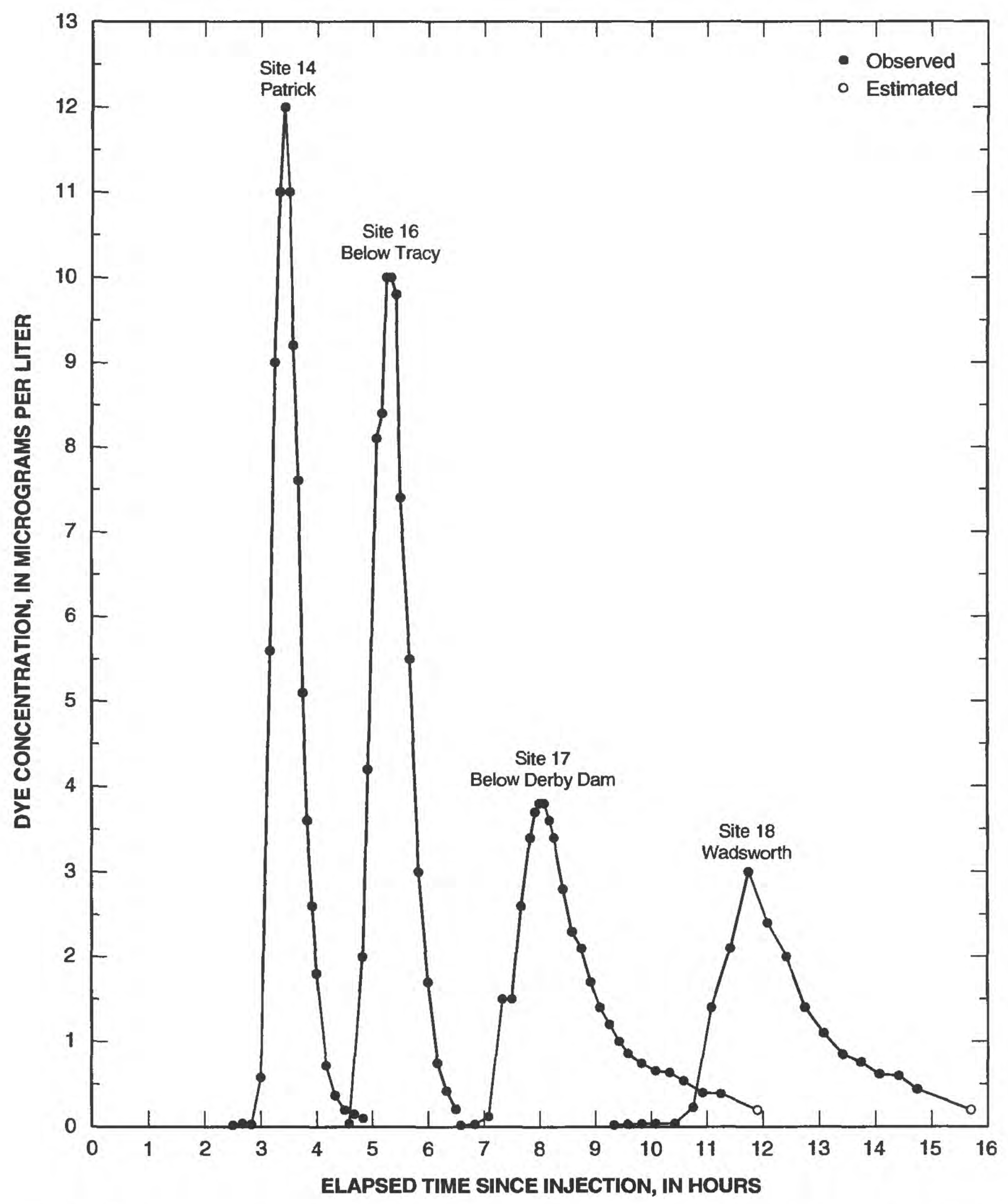

Figure 3. Observed response curves for Truckee River sites 14, 16, 17, and 18 for reach between Steamboat Creek at mouth near Sparks, Nev., and Wadsworth, Nev., April 30-May 1, 1999. See table 1 for full site names. 


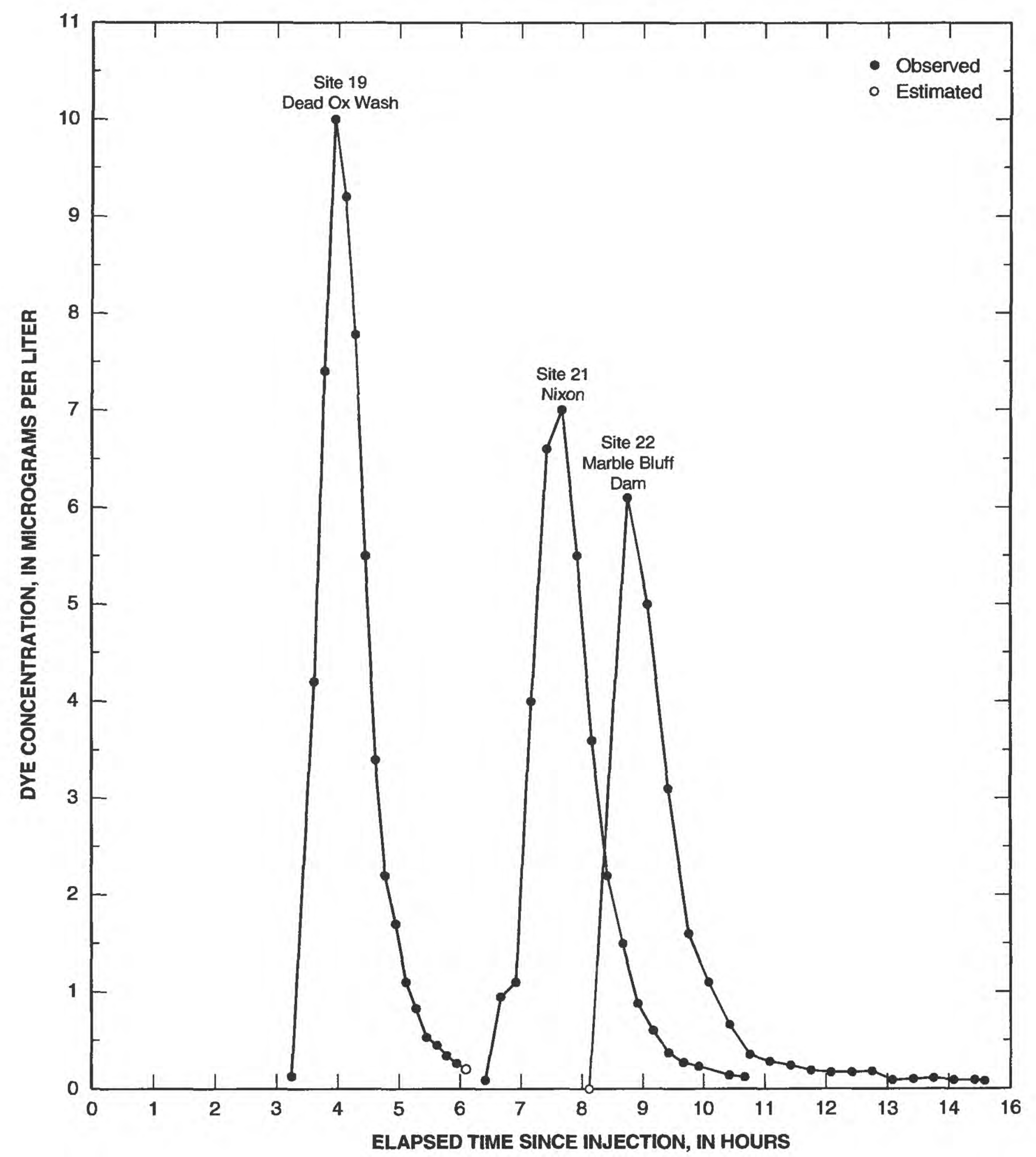

Figure 4. Observed response curves for Truckee River sites 19, 21, and 22 for reach between Wadsworth, Nev., and Marble Bluff Dam near Nixon, Nev., April 28, 1999. See table 1 for full site names. 


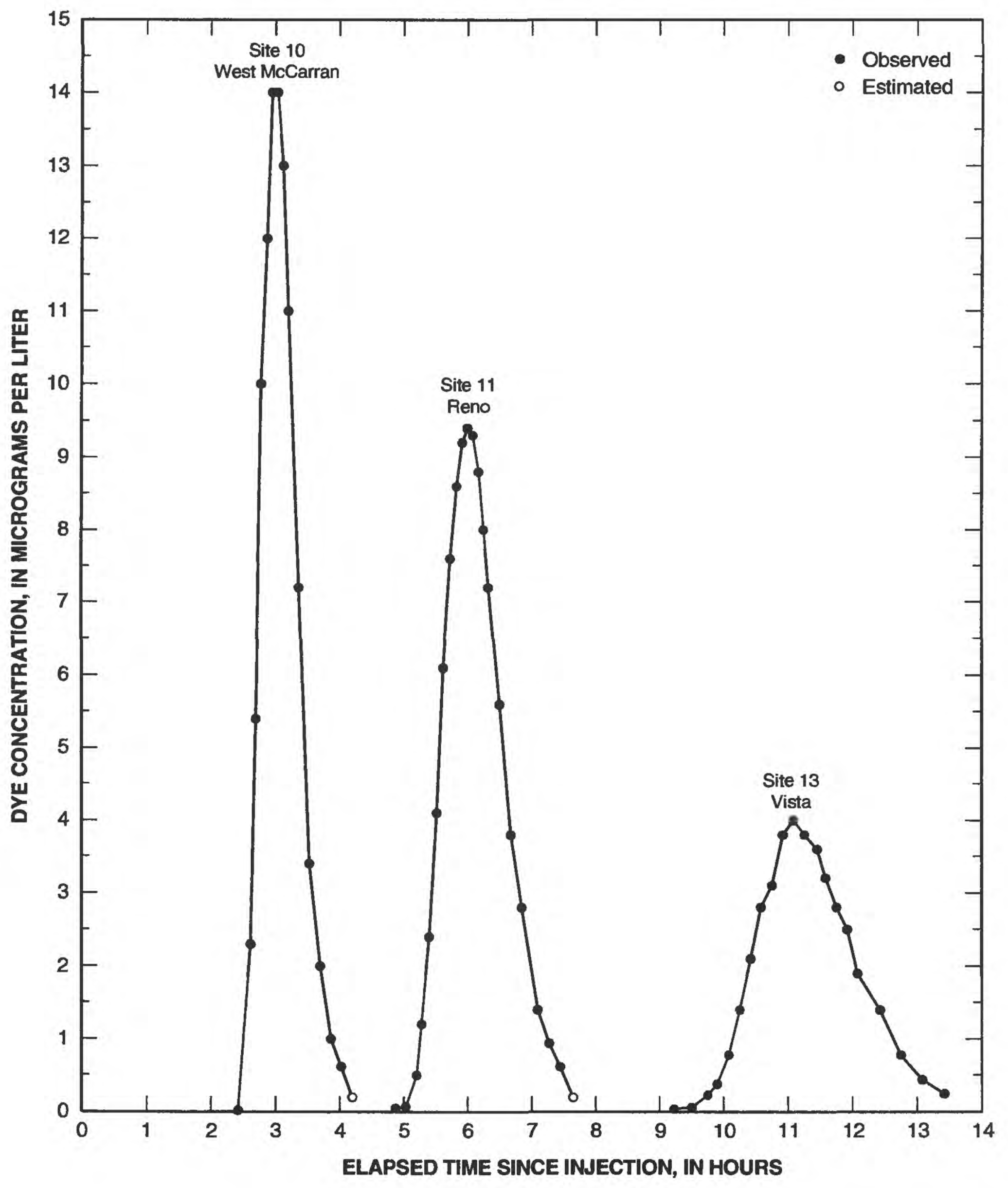

Figure 5. Observed response curves for Truckee River sites 10, 11, and 13 for reach between Mogul, Nev., and Vista, Nev., August 25, 1999. See table 1 for full site names. 


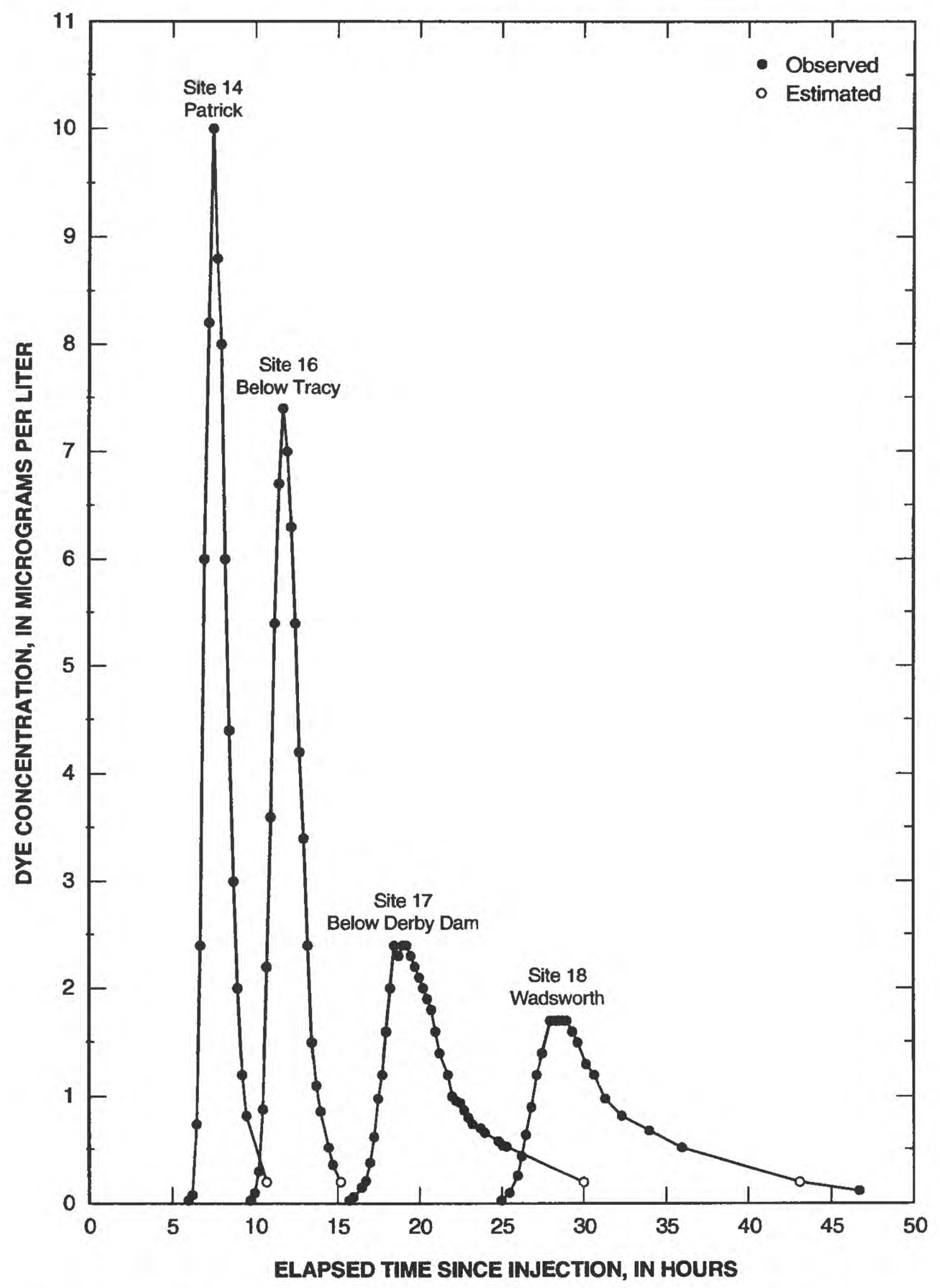

Flgure 6. Observed response curves for Truckee River sites 14, 16, 17, and 18 for reach between Steamboat Creek at mouth near Sparks, Nev., and Wadsworth, Nev., August 18-20, 1999. See table 1 for full site names. 


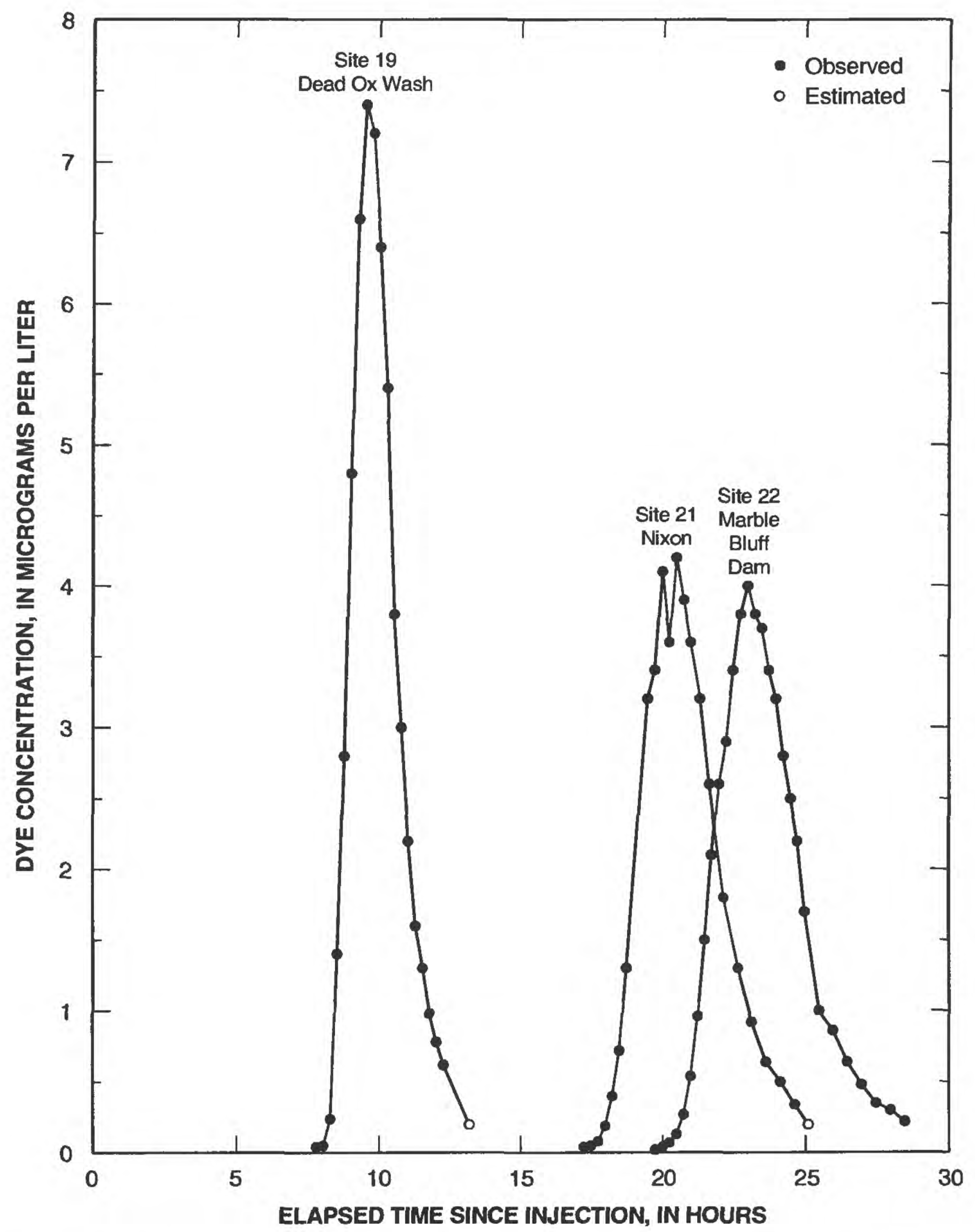

Figure 7. Observed response curves for Truckee River sites 19, 21, and 22 for reach between Wadsworth, Nev., and Marble Bluff Dam near Nixon, Nev., August 16-17, 1999. See table 1 for full site names. 


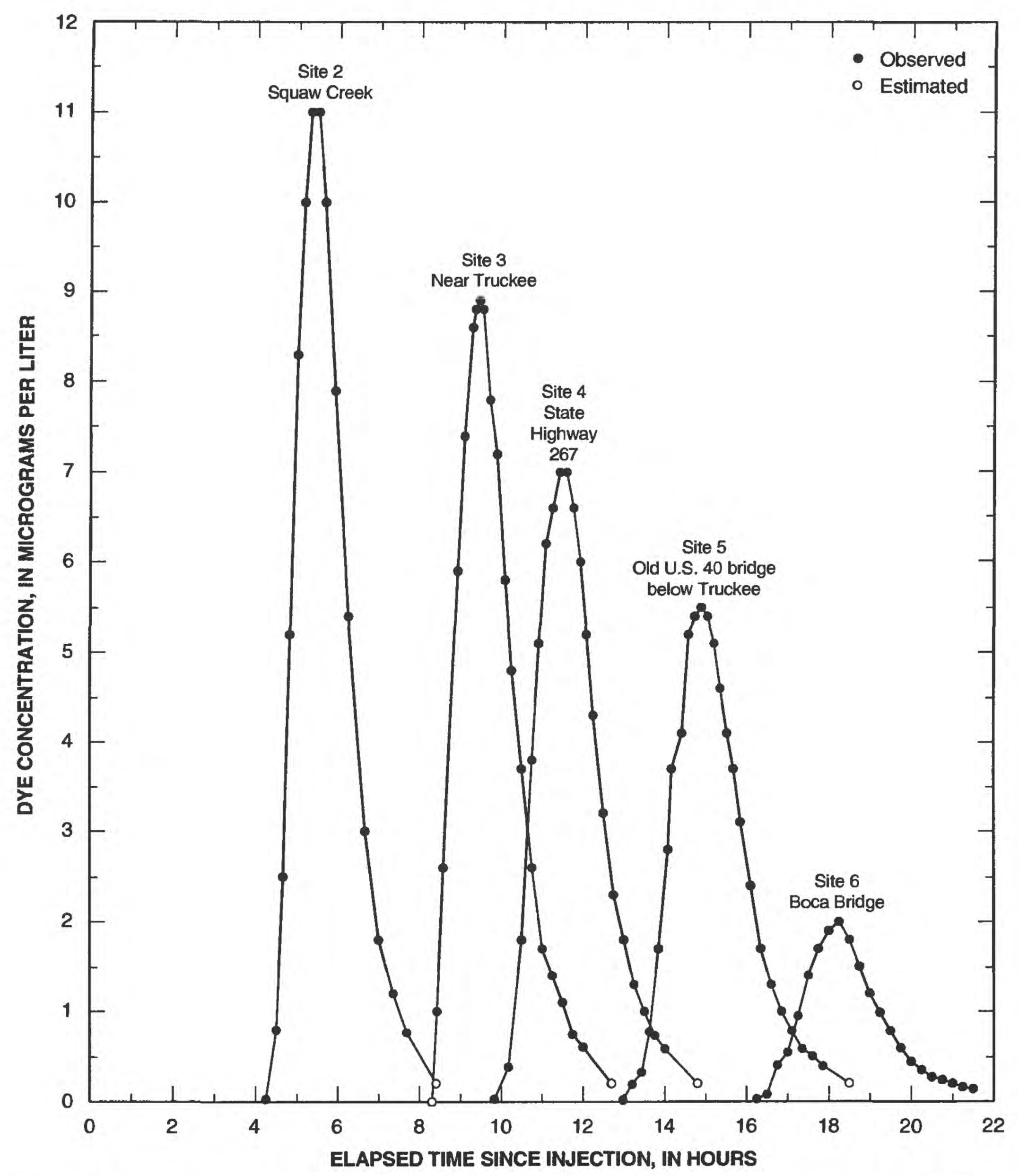

Figure 8. Observed response curves for Truckee River sites 2 through 6 for reach between Tahoe City, Calif., and Boca Bridge near Truckee, Calif., September 14-15, 1999. See table 1 for full site names. 


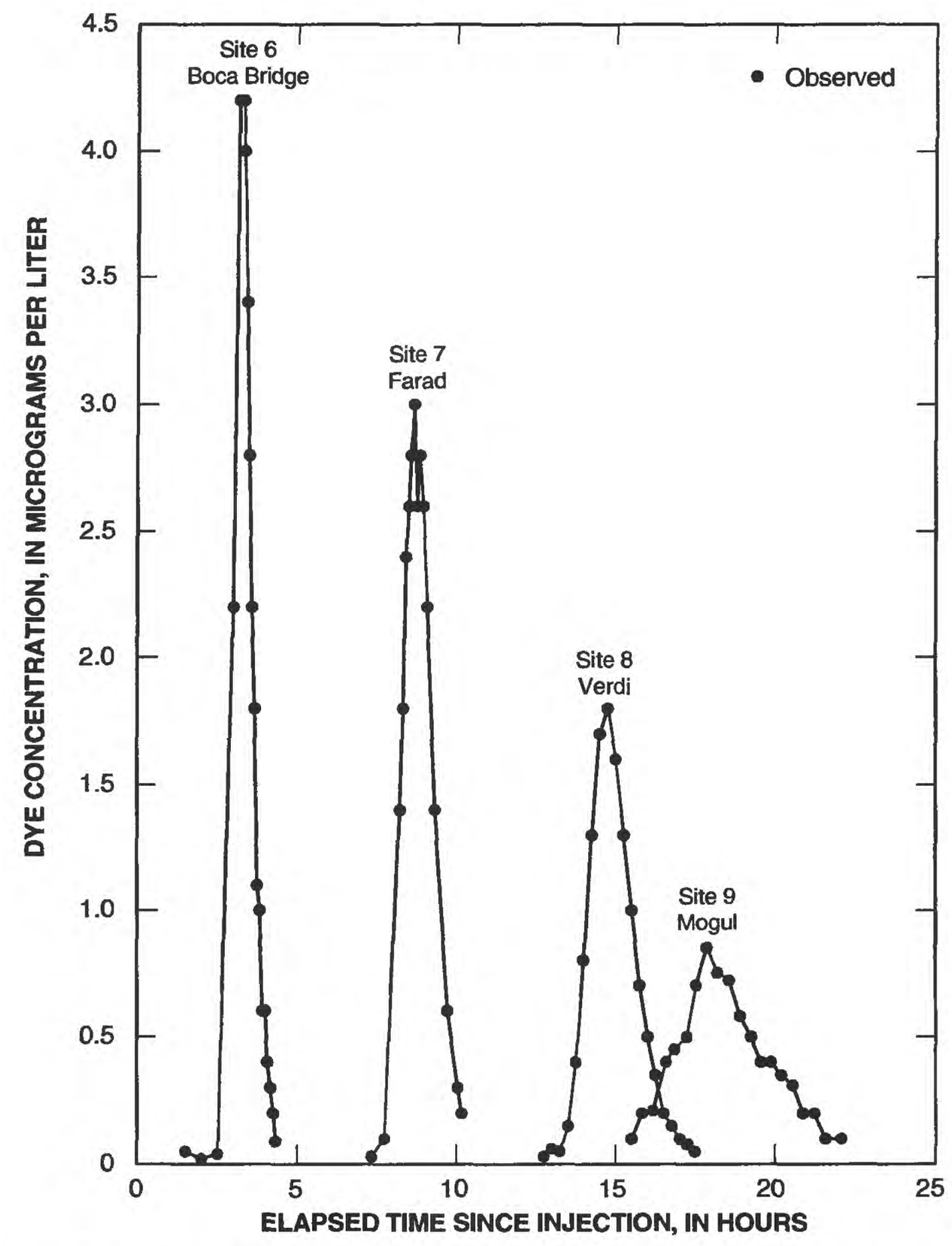

Figure 9. Observed response curves for Truckee River sites 6 through 9 between old U.S. Highway 40 bridge near Truckee, Calif., and Mogul, Nev., September 1920, 1999. See table 1 for full site names. 